ARCHIVO ESPAÑOL DE ARTE, LXXXIV, 336

OCTUBRE-DICIEMBRE 2011, pp. 355-378

ISSN: 0004-0428

\title{
MIGUEL PRIETO Y LA ESCENOGRAFÍA EN LA ESPAÑA DE LOS AÑOS TREINTA'
}

\author{
Miguel Cabañas Bravo \\ Instituto de Historia, CCHS, CSIC
}

Las tres grandes vertientes en las que el pintor Miguel Prieto (1907-1956) plasmó su creatividad fueron la pintura-dibujo, el diseño gráfico y la escenografía. Esta última, que fue en la que más énfasis puso tanto en su acercamiento a la vanguardia y el compromiso socio-político de los años treinta, como en los años finales de su trayectoria en el exilio mexicano, no ha sido suficientemente atendida. Este artículo, centrado en esa etapa española, analiza y pone en valor la aportación a la escena de Prieto coincidente con esos momentos de construcción de la joven II República y la convulsión de la Guerra Civil, que principalmente se plasmó en la escenificación de espectáculos de guiñol (extraídos del repertorio clásico o expresamente escritos por Alberti, Dieste, Lorca y otros jóvenes inquietos), ya que su tradición y clara aceptación popular los convertían en adecuado instrumento para encauzar la agitación y propaganda que querían sembrar el teatro revolucionario y la creatividad más avanzada y comprometida.

Palabras clave: Miguel Prieto; Escenografía; Decorados; Guiñol; Teatro revolucionario; II República Española; Guerra Civil Española; Exilio de 1939.

\section{MIGUEL PRIETO AND SET DESIGN IN SPAIN DURING THE 1930'S}

The artist Miguel Prieto (1907-1956) worked in three main areas: painting-drawing, graphic design and set design. The latter was the one in which he demonstrated most interest in avant-garde and political commitment during the thirties, but due to his subsequent Mexican exile, has not been dealt with in recent research. This article, focused on his years in Spain, analyses his contributions to scenic design. Prieto's first professional period, when he worked for the puppet theatre, coincided with the young Second Republic and then the convulsion of the Civil War. This popular genre was utilized for agitation, propaganda and the revolutionary theatre, and adopted both the classical repertoire and modern works by Alberti, Dieste, Lorca and other committed youthful intellectuals.

Key words: Miguel Prieto; Set design; Puppet theatre; Revolutionary theatre; Spanish Second Republic; Spanish Civil War; Exile of 1939.

${ }^{1}$ Este artículo se enmarca en el proyecto Arte y artistas españoles dentro y fuera de la dictadura franquista (P.N. de I+D+i, MICINN, Ref. HAR2008-00744). 
La incorporación del ensanchado pintor y exiliado Miguel Prieto Anguita (Almodóvar del Campo 1907-Ciudad de México 1956) al panorama del arte español del siglo XX es más bien reciente. Hasta no hace mucho, realmente era muy poco lo que se venía sabiendo sobre el alcance de las diferentes dimensiones creativas de esta figura plural de nuestro arte contemporáneo. Resultaba frecuente, sin embargo, las alusiones a este creador manchego en las historias del arte del siglo XX españolas y mexicanas, las cuales anotaban su nombre y puntuales producciones entre las presencias e hitos destacados de su desarrollo. Pero, a la postre, se convertía en un artista escurridizo, cuya diversificada aportación terminaba pasando bastante desapercibida para ambas historiografías. En los últimos años, por el contrario, unido al aumento de la investigación sobre el desarrollo del arte español durante los años treinta y su continuidad en el exilio -y a la revisión sobre sus protagonistas-, la figura de Miguel Prieto ha venido cobrando una mayor dimensión y una evidente recuperación, que cada vez demanda más indagación sobre nuevos aspectos, como el que nos proponemos desarrollar aquí respecto a los inicios de su contribución al mundo de la escenografía, entendida ésta de un modo extenso, muy combativo y especialmente insistente en la fórmula popular del guiñol, la cual servirá de precedente a la diversificación y los logros alcanzados con sus escenografías para la danza y el teatro en México, tras su forzado exilio en 1939; aspecto este último que, junto al de la fortuna crítica que ha tenido el artista manchego en las últimas décadas, ya hemos analizado en otro lugar².

Como ya avanzábamos allí, acaso ha habido distracción sobre el pintor, debida tanto a la genérica desconexión respecto al curso creativo seguido en el solar español como a la siempre difícil adscripción a lo meramente mexicano, que corrientemente se detecta en esta historiografía al tratar de los artistas del exilio de 1939. Igualmente contribuyó a ello su temprana muerte, acaecida en 1956 y apenas seguida en la capital azteca de la organización de unas cálidas muestras y homenajes, que, pese a haber dado una amplia visión de su extenso trayecto vital y profesional $^{3}$, no tardaron en caer en el olvido. Con todo, dada la fuerte, comprometida y sucesiva presencia de Miguel Prieto, desde inicios de los años veinte a mediados de los cincuenta, en los panoramas creativos avanzados de ambos países y sus situaciones socio-políticas y culturales, su revisión sólo era cuestión de tiempo.

La variada labor artística de este manchego se vehiculó y plasmó en tres áreas principales: la pintura-dibujo-grabado, el diseño gráfico y la escenografía. Sus más notables contribuciones parecen provenir de estos dos últimos aspectos, pese a que hay mucho por aclarar sobre el primero. Estas tres áreas creativas, de hecho, fueron en las que más se insistió tras su muerte 4 ,

2 La ponencia "Miguel Prieto y la escena en el exilio mexicano", presentada en el congreso Segundas jornadas sobre el exilio teatral republicano de 1939, celebrado en la Universitat Autònoma de Barcelona (10-11/3/2011), que se prevé publicar en Annals of Contemporay Spanish Literature, Temple (Philadelphia), 2012.

3 Benítez, Fernando et al.: "Homenaje a Miguel Prieto (1907-1956)" Novedades. México en la Cultura 388, México D.F., 26-8-1956 (Textos de Fernando Benítez, Juan José Arreola; G. García Cantú, H. Labastida, Enrique González Casanova, E. Poniatowska, Josep Renau, Gabriel García Narezo, A. Henestrosa, J. J. Crespo de la Serna, Miguel Guardia, Ceferino Palencia); Renau, José et al.: "Miguel Prieto ha muerto", Boletín de Información. Unión de Intelectuales Españoles, n. ${ }^{\circ}$ 2, México D.F., 15-10-1956, pp. 7-10 (Textos de Josep Renau, pp. 7-9; Juan Rejano, p. 9; Adolfo Sánchez Vázquez, pp. 9-10 y Gabriel García Narezo, p. 10); Rivas Cherif, Cipriano: "El teatro pictórico de Miguel Prieto", El Nacional (Suplemento Dominical) 505, México D.F., 2-9-1956, p. 3.

4 "La obra de los desterrados españoles en México", Boletín de Información. Unión de Intelectuales Españoles, n. ${ }^{\circ}$ 5, México D.F., 1957, pp. 8-23; MARTíneZ, Carlos: Crónica de una emigración: la de los republicanos españoles en 1939, México D.F., Libro-Mex, 1959. p. 137; Rejano, Juan: "Pintura de Miguel Prieto", Boletín de Información. Unión de Intelectuales Españoles, 14, México D.F., Abril-Mayo 1961, p. 39; Souto Alabarce, Arturo: "Pintura"; SUÁREZ, Luis: "Prensa y libros, periodistas y editores"; BENÍNEZ, Fernando: "Los españoles en la prensa cultural"; MendozA-López, Margarita: "Teatro"; y Mantecón, Matilde: "Índice biobibliográfico del exilio español en México", en Reyes Nevares, Salvador (dir.): El exilio español en México, 1939-1982, México D.F., Salvat-FCE, 1982, pp. 433470, 601-612, 623-631, 633-646, 837, respectivamente. 
mientras que en España, más tarde, el interés se centró en su presencia entre la vanguardia y su compromiso republicano ${ }^{5}$. En la década de los noventa, además, empezó a profundizarse en su influyente papel pionero en el diseño gráfico mexicano ${ }^{6}$; al tiempo que, en España, comenzaron a examinarse nuevas cuestiones, relacionadas con sus orígenes y primera trayectoria ${ }^{7}$, sus acercamientos a las vanguardias y el surrealismo ${ }^{8}$ o su compromiso socio-político y su exilio9 . Este interés por el manchego continuó en aumento, hasta culminar, al cumplirse en 2007 el centenario de su nacimiento, en una gran muestra retrospectiva, que unida a otras actividades paralelas, dieron un gran avance hacia un mejor conocimiento de muchos de los aspectos aludidos ${ }^{10}$.

La indagación sobre la vertiente escenográfica, que fue en la que más énfasis puso Prieto tanto en su acercamiento a la vanguardia y el compromiso socio-político durante los años treinta, como en los años finales de su trayectoria en el exilio mexicano, con todo, pese a unas primeras e interesantes exploraciones a su muerte ${ }^{11}$ y algunos análisis genéricos más tardíos, que han insistido en su contribución al guiñol español y a la escenografía teatral mexicana ${ }^{12}$, se ha ido

5 Pérez Contel, Rafael: Artistas en Valencia 1936-1939, Vol. 1, Valencia, Generalitat Valenciana, 1986, p. 237 y Alix Trueba, Josefina (dir.): Pabellón Español 1937. Exposición Internacional de París (cat. expo.), Madrid, Ministerio de Cultura, 1987, p. 237.

6 Medina, Cuauhtémoc: "Diseño antes del diseño", en Diseño antes del diseño, México D.F., Museo Carrillo Gil, INBA, 1991; BeníteZ, Fernando: "Recuerdo de Miguel Prieto", La Jornada, México D.F., 6-8-1991; Soler, Martí: "Miguel Prieto, entre impresores y tipógrafos", en VALENDER, J. et al.: Los refugiados españoles y la cultura mexicana, México D. F., El Colegio de México, 1999, pp. 255-265 Soler 1999, pp. 255-265. En tal contribución, por otro lado, también se centraron las exposiciones-homenaje que tributaron a Prieto en la capital azteca el Museo de Arte Contemporáneo Carrillo Gil en 1996 -Homenaje a Miguel Prieto. Código Tipográfico- y la Galería Metropolitana en noviembre de 1999 -Homenaje a Miguel Prieto-; así como el volumen colectivo que dedicaron a este tema varios especialistas (Benítez, Fernando; Martí Soler; Luis F. Gallardo; Federico Álvarez; Vicente RoJo: Miguel Prieto: Diseño gráfico, México D.F., Era/INBA/UNAM/UAM, 2000).

7 DíAz, Juan Antonio (coor.): Castellanos sin Mancha, Madrid, Celeste, 1999, pp. 134-140; SERrANo DE LA CrUZ, Angelina: Las artes plásticas en Castilla-La Mancha. De la Restauración a la II República (1875-1936), Toledo, Junta de Comunidades de Castilla-La Mancha, 1999, pp. 359, 369, 407-410; García Minguillán, M. ${ }^{a}$ Dolores (comisaria): Miguel Prieto Anguita. La mirada inquieta de un artista comprometido (cat. expo.), Almodóvar del Campo, Ayto.JJ.CC. de Castilla-La Mancha, 2001 y Álvaro OÑA, F. Javier: "Miguel Prieto, cronista de guerra. Pintor de batalla (Almodóvar del Campo, 1907-Méjico, 1956)", Revista Campo de Calatrava, 6, Puertollano, 2003, pp. 81-104 y Miguel Prieto. El arte como lucha, el soldado como artista, Ciudad Real, Ediciones C\&G, 2004.

${ }^{8}$ García de Carpi, Lucía, y Josefina Alix Trueba (comisarias): El surrealismo en España (cat. expo.), Madrid (MNCARS, X/1994-I/1995), MCU-BBV, 1994, pp. 392, 367.

9 Cabañas Bravo, Miguel: Artistas contra Franco, México D.F., UNAM, 1996, pp. 37-91; Cabañas Bravo, M.: "El exilio en el arte español del siglo XX”, en CABAÑas BRAvo, M (coor.): El arte español del siglo XX. Su perspectiva al final del milenio, Madrid, CSIC, 2001, pp. 287-315; CaBañas Bravo, M.: "De la Mancha a México: la singular andanza de los artistas republicanos Gabriel García Maroto y Miguel Prieto", Migraciones y exilios. Cuadernos de la AEMIC 6, Madrid, diciembre 2005, pp. 43-63.

${ }^{10}$ Bonet, Juan Manuel; Jaime Brinuega y Juana María Perujo (comisarios): Miguel Prieto. La armonía y la furia (Cat. expo. Ciudad Real: La Merced; Toledo: Museo de Santa Cruz; Madrid: Residencia de Estudiantes; Valencia: La Nau, noviembre 2007-diciembre 2008. Textos de J. M. Perujo, pp. 25-66; J. Brihuega, pp. 69-87 y J. M. Bonet, pp. 89116), Madrid, SECC-E. P. Don Quijote, 2007; Fernández Santamaría, Manuel; Julián López García y M. ${ }^{a}$ Dolores García-Minguillán: El tiempo y Miguel Prieto. Conociendo a Miguel Prieto, Almodóvar del Campo, Ayto. de Almodóvar, 2007, s.p.

11 Rivas Cherif: Op. cit., 1956, p. 3; Guardia, M.: "Teatro en México", en Benítez, F. et al.: Op. cit., 1956.

12 García Crespo, Nuria: "Miguel Prieto, artista", en Alted, A., y M. Llusia (dirs.): La cultura española del exilio republicano español de 1939, Vol. 2, Madrid, UNED, 2003, p. 55-62; Ayuso, Adolfo: "Miguel Prieto, director de La Tarumba. El guiñol en defensa de la República", Fantoche 1, Calatayud, octubre 2007, pp. 48-61; ToRRAs, Javier: "Miguel Prieto: Pintura, escenografía y tipografía", Info-arte. Revista Digital de Arte, http://www.infoartedigital.com/ arte/index.php?option=com_content\&task=view\&id=29\&Itemid=27 [consulta 23-02-2011].

Arch. esp. arte, LXXXIV, 336, octUBRE-DICIEMBRE 2011, 355-378, ISSN: 0004-0428 
postergando, sin que haya recibido un sólido trato específico. Dadas las limitaciones de espacio, no podemos tratar aquí este tema con la extensión y exhaustividad que merece, pero si podemos hacer un análisis aproximativo sobre las principales contribuciones de Miguel Prieto a la escena española en los convulsos años treinta. Tal aportación, al igual que las del resto de sus facetas creativas, estuvo hondamente condicionada por las circunstancias socio-políticas y artístico-culturales que le tocó vivir, las cuales fueron especialmente determinantes en el encauzamiento de su vida y su creatividad. Tres son, a grandes trazos, los diferentes y sucesivos momentos que, a partir de estos condicionantes, podemos registrar en el desarrollo de su creación y actuación escenográfica. El primero se corresponde con el período anterior a la guerra, que fue para Prieto esencialmente formativo, experimental y de concienciación socio-política; el siguiente comprende el período bélico mismo, en el cual el artista agudizó el compromiso y las actuaciones de urgencia, y, finalmente, sucedió el largo período del exilio mexicano, en el que gradualmente fue reactualizando y llevando más allá sus anteriores experiencias escénicas. Dejando aparte este último, que ahora sólo apuntaremos, los otros dos son en los que se centrará nuestro análisis.

\section{Formación y concienciación socio-politica de un artista}

Durante siglos, realismo e idealismo coexistieron y se fusionaron en La Mancha en diferente grado y proporción. Quizá las tierras manchegas imprimen a sus naturales cierto carácter de humano compromiso y solidaridad, difícil de abandonar, y, por ello mismo, acaso no le falte un tanto de quijotismo a la trayectoria vital y profesional del concienciado artista Miguel Prieto, quien el 18 de noviembre de 1907 nacía en Almodóvar del Campo, en el seno de una familia de tradición campesina (Isidro Prieto y Sofía Anguita, que tuvieron tres hijos más), aunque su padre se haría mecánico-maquinista de la Electro (la Electro Harinera Panificadora, que suministraba electricidad, harina y pan a Almodóvar). Hasta 1916 Miguel cursó los estudios primarios y, luego, siguiendo los deseos paternos, ingresó en la Academia Politécnica para especializarse en matemáticas y ser un buen técnico mecánico. Dos años después, en 1918, principió ya su formación artística en Puertollano (Ciudad Real), en el taller de un primo de su padre, el escultor y decorador Manuel Santos, quien le inició en el mundo del dibujo y del diseño y modelado decorativo. "Durante ese tiempo - dirá el escultor en una autobiografía inédita de 1950- yo aprendí todo lo referente al dibujo y al modelado decorativo, desempeñando por varios años el cargo de diseñador y modelista"13.

Su vocación por la pintura, con todo, le hizo trasladarse a Madrid en 1924, con el permiso de su padre, para completar su formación, aunque nunca pasó por academias oficiales. Se sostuvo allí con varios oficios, entre ellos el de pintor de brocha gorda, mientras estudió por su cuenta, frecuentando el Museo del Prado y los estudios de los escultores Victorio Macho y Julio Prat y el del pintor Julio Moisés (quien en 1923 había fundado en Madrid su Academia Libre), aunque su vocación pronto se centró sobre la pintura, la escenografía y el diseño tipográfico. Una copia de un Velázquez del Museo del Prado -o quizá del óleo Por la Patria, del profesor de la Academia de San Fernando Juan Antonio Benlliure, copia conservada hoy-, le valió un pensión en Madrid por dos años de la Diputación de Ciudad Real (1926-1927).

$\mathrm{Su}$ afición al teatro ya se iba manifestando por entonces, al tiempo que se fortalecía en el ejercicio del retrato y frecuentaba Ciudad Real, como ejemplifica el retrato al óleo que realizó en 1928 de Juanita de Mateo, joven distinguida a quien conoció en una representación del Teatro

13 Bonet/Brihuega/Perujo, Op. cit., p. 26. 
Cervantes ${ }^{14}$. Un año después, realizó el servicio militar en el Ministerio de Guerra, vinculado a su sección de cartografía, imprenta y editorial (estuvo adscrito a la Brigada Obrera y Topográfica del cuerpo del Estado Mayor). Todo aquello le permitió ir financiando y completando su formación, que parece ser que también amplió como escenógrafo en el Teatro Escuela de Arte (TEA) que, en el Teatro María Guerrero de Madrid, dirigió Cipriano Rivas Cherif, cuñado de Manuel Azaña y buen amigo desde entonces del almodovense. A este director del Teatro Español, de hecho, desde sus admiraciones infantiles por el guiñol y el ballet, siempre le interesó la incidencia del arte en el teatro y, quizá, Prieto incluso escuchara los recuerdos y el planteamiento que, en diciembre de 1932, expuso en su conferencia "El arte en el teatro"15.

Fue también en aquel Madrid del primer lustro de los años treinta, en el que el almodovense inició su trayectoria creativa. Se trataba del ilusionado período de construcción de la II República, durante el cual Prieto no sólo comenzará a sonar entre los pintores avanzados, sino que asimismo se casará -en Madrid, en noviembre de 1931, con su paisana manchega Ángela Ruiz Ramírez- y formará su propia familia (en 1933 nace su primer hijo, Miguel), a la vez que irá acentuando tanto su compromiso político-social como sus relaciones con destacados intelectuales y creadores que lo compartían.

Poco antes de la llegada de la República, de hecho, el reputado crítico Manuel Abril, salvaba su obra y reproducía un Paisaje de ambiente manchego de entre lo exhibido en la "Exposición permanente", colectiva celebrada en la primera quincena de febrero de 1931 en el Círculo de Bellas Artes y considerada por él "lamentable, horrorosa"16. Seguidamente, Miguel Prieto continuó reforzando su presencia como pintor en la capital española a través de sus dos primeras muestras individuales, celebradas en el Ateneo. La primera de ellas, compuesta por veintiuna obras, fue inaugurada el 2 de enero de $1932^{17}$, siendo prorrogada por su alta concurrencia hasta el 20 de enero ${ }^{18}$. Su principal valedor siguió siendo el crítico Manuel Abril, también autor del texto del catálogo, el cual reprodujo en parte en su crónica para la revista Blanco y Negro, ilustrada con los cuadros de Prieto Canción y Taberna de Madrid. Allí insistió Abril en considerarle un artista y pintor "con mayúscula", que conseguía "la gracia y la fuerza con señales evidentes de criatura dotada", que le colocaban entre los más destacados jóvenes de valía llegados recientemente al "arte de ahora"19. Igualmente obtuvo buenos comentarios de críticos como Juan de la Encina, que lo vio bien pertrechado artísticamente de cara al futuro ${ }^{20}$, y de Luis Gil Fillol, que

${ }^{14}$ Ibidem, p. 27.

15 Tuvo lugar el domingo día 4, organiza por la Asociación Profesional de Estudiantes de Bellas Artes, y en ella Rivas Cherif comenzó evocando sus recuerdos de infancia y el antiguo teatro de guiñol que se levantaba en los solares del actual Hotel Ritz, la aparición del ballet ruso y la Paulowa, etc. Hizo también un repaso de las diferentes corrientes teatrales, hasta llegar a la deshumanización de la escena con la sustitución del actor por la marioneta. Acabó analizando la conciliación de las diversas tendencias en el teatro de Morin, de donde surgieron las formas modernas de la escena europea y los sucesivos ensayos españoles, como el teatro libre de Alejandro Miquis, los diversos realizados por él, el Mirlo Blanco y el Caracol. Añadía a ello la labor conjunta de Martínez Sierra y la Bárcena, la de algunos escenógrafos y de Margarita Xirgu, que decía que eran quienes habían marcado las diferentes etapas para la renovación del teatro español, en su tradición guiada por la inspiración moderna ("Conferencia del Sr. Rivas Cherif. El arte en el teatro", El Sol, Madrid, 6-12-1932, p. 3).

16 ABRIL, Manuel: "Rumbos, exposiciones y artistas", Blanco y Negro, Madrid, 15-2-1931, pp. 21 y 23.

17 "Arte y Artistas. Exposición Miguel Prieto", $A b c$, Madrid, 2-1-1932, p. 27; "Vida artística. Ateneo de Madrid. Exposición Miguel Prieto", El Sol, Madrid, 2-1-1932, p. 2; "Ateneo de Madrid. Exposición Miguel Prieto", La Libertad, Madrid, 2-1-1932, p. 9.

18 “Arte y Artistas. En el Ateneo de Madrid”, Abc, Madrid, 15-1-1932, p. 35.

19 ABRIL, Manuel: "Rumbos, exposiciones y artistas... Exposición Miguel Prieto", Blanco y Negro, Madrid, 10-11932 , p. 38

${ }^{20}$ Encina, Juan de la: "Nueva colmena española", El Sol, Madrid, 16-1-1932, p. 1. 
aludió a su "preocupación cezannista" y su "rica potencia constructiva"21. Esta buena acogida, acaso indujo a Abril a incluirle, en febrero de 1932, entre la representación madrileña de la muestra organizada por la Sociedad de Artistas Ibéricos en el Ateneo Mercantil de Valencia ${ }^{22}$.

Igualmente, en la siguiente individual de Prieto, presentada el 13 de mayo de 1933 en el Ateneo madrileño ${ }^{23}$, éste volvió a obtener el favor de la crítica avanzada. Exhibió entonces catorce cuadros, en su mayoría figuras y paisajes, a veces combinados y de gran fuerza expresionista y dirección avanzada y social, entre los que se encontraron los titulados Terrateniente, Lavanderas, Hortelana o Central eléctrica, este último con todo un "desbarrado" sentido estético, según comentó $A b c^{24}$. En el mismo Ateneo le dedicó el crítico Enrique Azcoaga, el día 26, la conferencia titulada "Color y gesto", con la que insistió en "la existencia de poesía y preocupación humana" y en el rápido descubrimiento de "un fondo social, substancial en sus cuadros"25, y asimismo, el propio Abril, reanudó sus positivos comentarios sobre la abundante y "alta" pintura del manchego y la indiferencia u hostilidad de la crítica y las gentes ${ }^{26}$. Con todo, en lo estético, su producción iría evolucionando -especialmente a partir de la Revolución de Asturias de 1934- hacia un realismo cada vez más comprometido, aunque sin olvidar los recursos surrealistas.

Prueba, por otro lado, de la creciente concienciación y compromiso que venía adquiriendo Miguel Prieto fue que, ya en 1933, al crearse en Madrid la Asociación de Escritores y Artistas Revolucionarios (AEAR), filial de su homónima francesa, fundada en marzo de 1932, el almodovense será uno de sus fundadores y primeros afiliados. Este singular compromiso pronto lo hizo expreso en muchas ocasiones y de múltiples modos. Así, de hecho, antes de su referida segunda individual, ya lo dejó claro en una conferencia que, precisamente bajo el título "Arte y revolución social", pronunció el 16 de marzo de 1933 en la Sección Sociológica del Fomento de las Artes de Madrid ${ }^{27}$. También lo hizo evidente respecto al teatro, cuando a comienzos de julio de 1933 firmó, junto a varios jóvenes artistas y escritores (Arturo Serrano Plaja, Rafael Dieste, Antonio Rodríguez Luna, Enrique Azcoaga, Alberto Fernández Mezquita, Rafael Alberti y otros), una carta abierta de adhesión, enviada a la prensa, en la que se solidarizaban con la protesta protagonizada en el Teatro Beatriz por Antonio Sánchez Barbudo, durante el estreno de la comedia en tres actos Santa Teresita del Niño Jesús, de Vicente Mena; carta que, de paso, aprovechaban para hacer una severa crítica a este tipo de literatura escénica, que extendían a la obra total de Mena, Muñoz Seca, Honorio Maura, etc. ${ }^{28}$.

${ }^{21}$ Gil Fillol, Luis: “Arte. La pintura metafórica de Miguel Prieto”, Ahora. Diario Gráfico, Madrid, 13-I-1932.

22 ABril, Manuel: "Exposición en Valencia”, Luz, Madrid, 27-2-1932, p. 9.

23 "Arte y Artistas. Ateneo de Madrid", $A b c$, Madrid, 12-5-1933, p. 40.

24 "Arte y Artistas. Pinturas de Miguel Prieto, en el Ateneo de Madrid", $A b c$, Madrid, 19-5-1933, p. 42.

25 “Convocatorias", Abc, Madrid, 24-5-1933, p. 35; "Conferencias. 'Color y gesto' por don Enrique Azcoaga", El Sol, Madrid, 26-5-1933, p. 5; "Ateneo de Madrid. Conferencia de Arte", La Libertad, Madrid, 26-5-1933, p. 2.

${ }^{26}$ ABriL, Manuel: "Rumbos, exposiciones y Artistas. Actualidad de diversas clases", Blanco y Negro, Madrid, 28-5-1933, p. 56

27 “Conferencias", El Sol, Madrid, 16-3-1933, p. 3 y "Convocatorias", Abc, Madrid, 16-3-1933, p. 42. Sito en la calle San Lorenzo 15, se trataba de un viejo centro social, recreativo y formativo, fundado en 1847, que actuaba como punto de reunión de los liberales e izquierdistas y no sólo ofrecía conferencias, sino que también se dedicaba a la instrucción de la clase obrera, proporcionando cursos de primaria, dibujo, aritmética, gramática y francés, para los niños por el día y para los socios y sus hijos adultos por la noche; centro al que seguiremos viendo vinculado a Prieto. En el momento de su conferencia, el presidente de su Sección Sociológica era E. Lorenzo y el problema más acuciante el del paro obrero, como evidencia la correspondencia y encuestas (véanse cartas de 25 y 30-1-1933. PS-Madrid, 734, 113, CDMH, Salamanca).

28 Araujo-Costa, Luis: "Veladas teatrales. Beatriz", La Época, Madrid, 30-6-1933, p. 4; MAurA, Honorio: "Lo ocurrido en el Teatro Beatriz", La Época, Madrid, 30-6-1933, p. 4; "El incidente derivado de unas protestas en el teatro Beatriz", El Sol, Madrid, 2-7-1933, p. 12; "El incidente del teatro Beatriz", Luz, Madrid, 3-7-1933, p. 11. 
Simultáneamente, tal compromiso del almodovense también se observa en sus dibujos para la revista Octubre, órgano de la AEAR dirigido por Alberti y María Teresa León, que, en su tercer número ${ }^{29}$, presentaba en su contracubierta el dibujo de Prieto "Puerto de Sevilla" (fig. 1). El artista denunciaba aquí el comportamiento esquirol en las huelgas de navegación

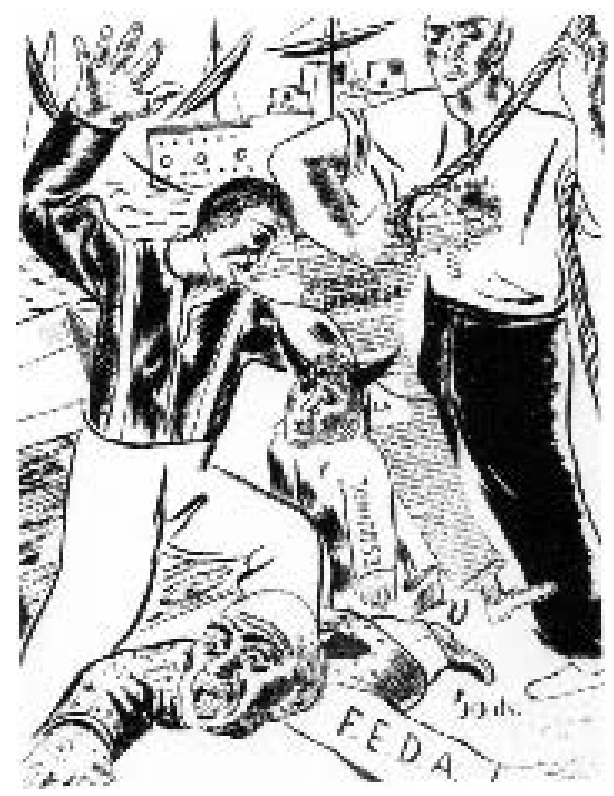

Fig. 1. M. Prieto: Puerto de Sevilla, contraportada de la revista Octubre, n. ${ }^{\circ} 3$, VIII-IX/1933. de cabotaje ${ }^{30}$, lo cual se vinculaba con la obra teatral de agitación, en un acto, Huelga en el puerto, de María Teresa León, publicada en el mismo número ${ }^{31}$. Además, con otros jóvenes artistas comprometidos (Alberto Sánchez, Antonio Rodríguez Luna, Josep Renau, Cristóbal Ruiz, Enrique Climent, Pérez Mateos, Darío Carmona, Salvador Bartolozzi, etc.), participó el manchego en la colectiva I Exposición de Artistas Revolucionarios, que fue la primera manifestación plástica promovida y organizada por la AEAR. Se celebró en el Ateneo madrileño, en los doce primeros días de diciembre de 1933, bajo el lema expreso: "El hecho de concurrir a esta exposición significa: estar contra la guerra imperialista, contra el fascismo, por la defensa de la Unión Soviética, junto al proletariado". La misma Octubre, junto a la reseña de la muestra, indicaba que en fecha muy próxima se inauguraría, en una fiesta a beneficio de la revista, una serie de obras "maldicientes, satíricas y revolucionarias", interpretadas por los fantoches del "Guiñol Octubre" 32 .

El guiñol, cuya tradición popular lo convertía en el más adecuado instrumento para encauzar la agitación y propaganda que pretendían sembrar el teatro revolucionario y la creatividad más avanzada y comprometida, llegó a ser durante estos años el principal

medio de Miguel Prieto para vehicular su compromiso social y revolucionario, al tiempo que se convirtió en una fuente inagotable de experiencias escénicas. En cuanto a los orígenes que vinculan al pintor manchego con este tipo de iniciativas, parece ser, según expuso la citada revista y se ha estudiado luego ${ }^{33}$, que un grupo de actores en paro se planteó realizar la compañía de teatro revolucionario "Octubre", aunque el proyecto quedó frustrado. Sin embargo, lo que sí logró consumarse fue el Guiñol Octubre, dirigido por Miguel Prieto y para el que Alberti, con intención de canalizar la agitación y propaganda, en 1934 escribió Bazar de la Providencia (Negocio), una farsa anticlerical con obispos que vendían reliquias y guardias civiles que los protegían. Esta obra del poeta, estrenada en junio de 1934 con el guiñol de Prieto ${ }^{34}$, la publicó Alber-

${ }^{29}$ Octubre n. $^{\text {o } 3 \text {, Madrid, Agosto-septiembre } 1933 .}$

30 Bonet/Brihuega/Perujo, Op. cit., p. 73.

31 LEÓN, María Teresa: "Huelga en el puerto", Octubre 3, Madrid, agosto-septiembre 1933, pp. 77-78.

32 "I Exposición de arte revolucionario", Octubre, n. ${ }^{\circ}$ 6, Madrid, abril 1934, pp. 16-17.

33 AZNAR, Manuel: "María Teresa León y el teatro español durante la guerra civil", Antrophos, n. ${ }^{0} 148$, Barcelona, septiembre 1993, p. 27 y AzNAR, M.: "El teatro español durante la Segunda República (1931-1939)", Monteagudo, n. ${ }^{\circ} 2$, Murcia, 1997, p. 49.

${ }^{34}$ Según Ayuso (Op. cit., 2007, p. 51), que sigue a Jaume Lloret (Breu història del titella a Alacant, en AA.VV.: El titella a Alacant, Alicante, Ajuntament d'Alacant/CAM, 1997, pp. 35-36), el 4 de marzo de 1934 hubo en Alicante 


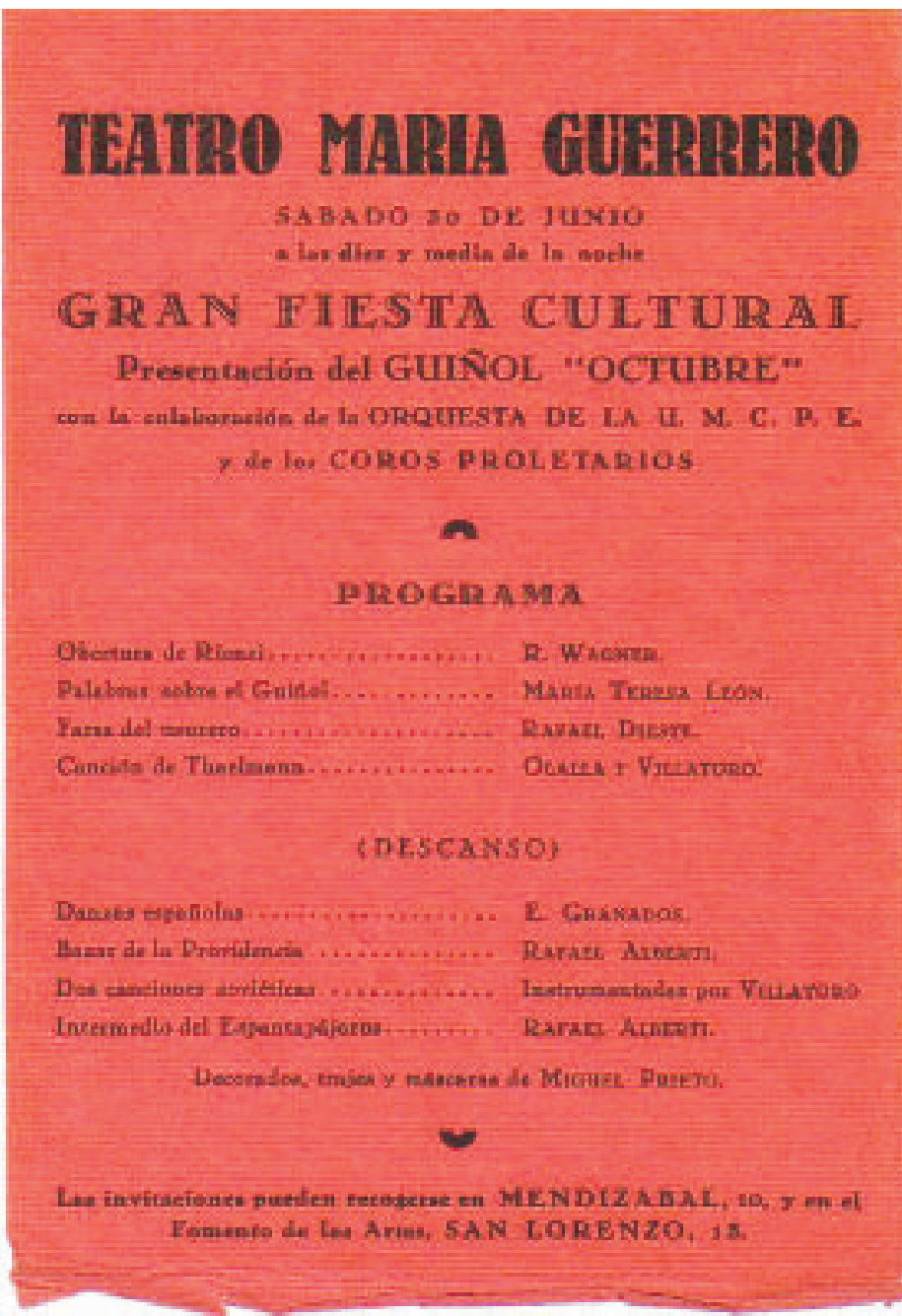

Fig. 2. Programa de la Fiesta de Presentación del Guiñol Octubre, 30-6-1934.

ti ese mismo año en Ediciones Octubre, junto a Farsa de los Reyes Magos, como Dos farsas revolucionarias ${ }^{35}$.

De hecho, un programa de mano del Teatro María Guerrero $^{36}$ (fig. 2) anunciaba, para el sábado 30 de junio de 1934, una "Gran fiesta Cultural" con motivo de la "Presentación del Guiñol Octubre", para lo que se contaba con la colaboración de la Orquesta de la U.M.C.P.E. y de los Coros Proletarios. El programa, que indicaba claramente a Miguel Prieto como autor de los decorados, trajes y máscaras, se compuso, en su primera parte, de la interpretación de la Obertura de Rienzi, de R. Wagner; unas "Palabras sobre el Guiñol" por parte de María Teresa León; la representación de la Farsa del usurero, de Rafael Dieste, y la interpretación de la Canción de Thaelmann, de Olalla y Villatoro. Después del descanso, se ejecutó las Danzas españolas, de Enrique Granados, y se representaron el Barzar de la Providencia e Intermedio del Espantapájaros, de Alberti, intercalando entre ambas representaciones la interpretación de "Dos canciones soviéticas", instrumentadas por Villatoro. Curiosamente, uno de los dos lugares que el programa indicaba para recoger las invitaciones era el citado Fomento de las Artes, al que vimos vinculado a Prieto.

una representación previa de Bazar de la Providencia, que debió tratarse de un ensayo o preestreno y sobre el que no nos consta si fue interpretado por títeres o actores ni si Miguel Prieto tuvo alguna participación.

35 AZNAR: Op. cit., 1997, p. 49.

${ }^{36}$ El programa pertenece a la Biblioteca Kelin, y se mostró (aunque mal datado), al igual que el Bazar de la Providencia, en la exposición que se le dedicó a Rafael Alberti en 2003 (Bonet, Juan Manuel; Carlos Pérez y Juan PéreZ DE Ayala (comisarios): Entre el clavel y la espada. Rafael Alberti en su siglo. [Cat. expo. Madrid: MNCARS; Sevilla: CAAC, septiembre 2003-febrero 2004], Madrid, MCU-SECC, 2003, p. 239). 
A partir de esta nueva experiencia, que se sumaba a otras que comentaremos, el guiñol -del que el pintor manchego llegaría a ocuparse de casi todos sus detalles: frontispicios, telones, decorados, vestuario e incluso confección de los muñecos con pasta, papel, cola y yeso-, se convertiría para él en el instrumento esencial para materializar su compromiso y su apoyo a la acción revolucionaria. Él mismo, en unas nuevas notas autobiográficas de 1956, en cuanto al momento y finalidad de este instrumento creativo y de agitación, indicó:

Precisamente en la época en que Federico estaba en Argentina, hice yo mis primeros ensayos de guiñol con el poeta Rafael Alberti; ese guiñol se llamó Octubre y nuestro propósito fue el de montar un espectáculo que tuviera una finalidad política y literaria. Por aquel tiempo también escenifiqué en el Teatro Español en Madrid El retablo de Maese Pedro de Manuel de Falla, interpretado en la parte musical por la Orquesta Sinfónica de Madrid ${ }^{37}$.

Pero estos recuerdos, si seguimos a la prensa de la época, no son exactos; puesto que, previo a la presentación en junio de 1934 del Guiñol Octubre en el María Guerrero con las obras de Dieste y Alberti, en abril y mayo de ese mismo año ya habían tenido lugar tanto la representación del Español, como la llegada de Lorca, quien posiblemente pudo ver este trabajo de Prieto.

En efecto, desde finales del mes de abril la prensa madrileña se hizo eco del acto de "Conmemoración de Cervantes" que tendría lugar el 28 de abril de 1934 en el Teatro Español, en el cual el maestro Pérez Casas, al frente de la Orquesta Filarmónica, interpretaría un variado programa que incluía la primera representación en Madrid de El retablo de Maese Pedro de Falla, con fantoches y decorados de Miguel Prieto, figurines de Victorina Durán y dirección escénica de Rivas Cherif ${ }^{38}$. Este acto cervantino, que había recibido un gran impulso del ya exministro de Instrucción Pública Salvador de Madariaga y que culminaba otros tantos de la celebración de la Semana Cervantina ${ }^{39}$, tuvo lugar en el teatro y día indicados. Se estrenaba con él una nueva versión escénica de El retablo de Maese Pedro, ahora bajo la dirección de Rivas Cherif, los actores del TEA vestidos por Victorina Durán y un guiñol de fantásticas proporciones realizado y escenificado por Miguel Prieto; versión que venía a sumarse a las diferentes surgidas desde la primera representación de 1923 en el palacio de la princesa de Polignac en París. Se trató, además, prácticamente del "día de Falla", como destacó casi unánimemente la prensa, pues si por la tarde se representó la versión íntegra del guiñol amenizada por la Orquesta Filarmónica, por la noche le tocó el turno a la versión de danza del Amor brujo de Antonia Mercé "La Argentinita", animada por la Orquesta Sinfónica de Madrid. Sin embargo, aunque todos apreciaron y elogiaron el trabajo del almodovense, la versión no gustó por igual.

Así, el crítico de La Época, indicó que, "la propia imaginación suele, en general, satisfacer mejor las necesidades y acotaciones escénicas, que el más hábil metteur", y aunque "sería injusto negar momentos de emoción artística en el jugo de las marionetas discurridas por Miguel Prieto (...) no gana absolutamente [la partitura de Falla] en interés y emoción, cuando la escuchamos a través del espectáculo titiritesco"40. Para el crítico de El Sol, "el guiñol de Miguel Prieto, sus decorados y sus títeres" eran "deliciosos" y sus movimientos se solieron acompasar bien con la música, pero la totalidad del espectáculo -y especialmente su final- era "de un efec-

\footnotetext{
37 Bonet/Brihuega/Perujo, Op. cit., pp. 30-31.

38 "Conmemoración de Cervantes", $A b c$, Madrid, 26-4-1934, p. 43; "La Orquesta Filarmónica en el Español", $A b c$, 27-4-1934, p. 48 y "La Orquesta Filarmónica en el Español”, $A b c, 28-4-1934$, p. 48.

39 "De la conmemoración del Día de Cervantes", $A b c$, Madrid, 29-4-1934, p. 41.

40 V. E.: "Ecos musicales. El día de Falla", La Época, Madrid, 30-4-1934, pp. 3-4.
} 
to poco satisfactorio"41. Por el contrario, Gustavo Pittaluga opinó que, los muñecos, llenaron "de acción la recitación y el canto de los intérpretes musicales. Con un gran sentido, y en algunos casos pleno logro - tal el gran final de Don Quijote, [donde] los muñecos, sobre decoraciones del mismo Miguel Prieto, representaron una tragedia de Melisendra deliciosa- tal Los pirineos o El rapto" $^{\$ 2}$. Finalmente, a la muerte del escenógrafo, también Rivas Cherif se refirió a esta colaboración, describiendo así su escenografía:

Falla me confesó ser la primera vez que había quedado satisfecho de cuantos intentos hasta el momento hizo, repito, por realizar escénicamente la obra. Lo fue de Miguel Prieto. Su opinión, en primer lugar, fue decisiva en apoyo de la mía, y contra la vacilante del autor mismo, en pro de un realismo que, sin menoscabo del valor plástico de la representación, al ritmo que la música impone, hiciera resaltar la desproporcionada proporción, válgame la paradoja cervantina, entre los personajes reales y los imaginados, que otras veces se intentó en puro teatro de marionetas, unos y otros. En nuestro "Retablo" del Español, éste se armaba realmente en el escenario, ámbito natural de la Venta, y, acierto máximo de Prieto, Don Quijote se figuraba, como en primera fila y a un lado de la escena, por enorme figurón del que sólo acertaba a ver el público de la sala, las larguísimas piernas, oculto el resto del cuerpo por el cortinaje de un bastidor. Los pequeños decorados del retablo, los fantoches y su atavío, la ponderación de la luz, sobre todo, aun defectuosísima como era entonces la luminotecnia del teatro municipal de Madrid, me hicieron ver en aquel alarde del joven pintor, la posibilidad prometedora que había en su propósito, del que ya me habló de hacer un teatro español de marionetas ${ }^{43}$.

Por otro lado, además de esta colaboración en abril con el director del Teatro Español y las representaciones de junio con el Guiñol Octubre en el María Guerrero, desde hacía tiempo Prieto venía estrechando amistades y colaborando con otros jóvenes y comprometidos creadores ${ }^{44}$. De este modo, tales actuaciones las realizó el manchego en paralelo a la cooperación que mantuvo entre inicios de 1934 y 1936, como escenógrafo y actor, con las Misiones Pedagógicas, acompañando a Dieste y su Retablo de Fantoches, al igual que hicieron tanto Luis Cernuda, Emilio Prados y otros jóvenes escritores, como algunos inquietos creadores que intervinieron en el modelado de muñecos y en los decorados, como es el caso de La doncella guerrera, romance dramatizado por Dieste que llevaron en su repertorio y, cuyos personajes y decorados, fueron realizados por Miguel Prieto, Ramón Gaya, Cándido Fernández Mazas y Urbano Lugrís. Del mismo modo, se conservan testimonios y fotografías del paso del manchego por Zamora, Asturias (Castropol y Puente de Vega), Burgos y su provincia (entre julio y septiembre de 1934) o, acompañado de Cernuda, Prados, Quintín García y Bernabé Fernández Canivell, por Málaga y Vélez-Málaga en noviembre de $1934^{45}$, y habría que perfilar el papel exacto que cumplió Prieto en la dirección del guiñol ${ }^{46}$. Ese año de 1934, en el que además de otros trabajos sobre títeres en Madrid y la reafir-

41 S.: "El Teatro Español. El retablo de Maese Pedro y El amor brujo", El Sol, Madrid, 2-5-1934, p. 4.

42 Pittaluga, Gustavo: "La Argentina en Madrid", Diablo Mundo, n. ${ }^{\circ}$ 2, Madrid, 5-5-1934, p. 6.

43 Rivas CHERIF, Op. cit., 2-9-1956, p. 3.

44 Ejemplifica bien su círculo de amistades su presencia en el homenaje que, el grupo Frente Literario, dirigido por Francisco Burgos, tributó el 25 de abril de 1934 a Arturo Serrano Plaja por su éxito con su poemario Sombra indecisa; fiesta a la que también acudieron Alberti y María Teresa León, Timoteo Pérez Rubio y Rosa Chacel, Guillermo de Torre, Arconada, Delia Carril, Santos Balmori y muchos otros ("Fiesta literaria en honor de un poeta", La Libertad, Madrid, 25-4-1934, p. 5).

45 Reproducidas en Bonet/Brinuega/Perujo, Op. cit., pp. 30-34, 75-76.

46 Aunque siempre se cita a Dieste como director del Retablo de Fantoches, afirma Robert Marrast (El teatre durant la guerra civil espanyola. Assaig d'historia i documents, Barcelona, Institut del Teatre-Edicions 62, 1978, p. 8) que el 
mación de su compromiso estético, se documenta tan claramente la colaboración de Miguel Prieto con las Misiones Pedagógicas, podría decirse que también es en el que el manchego descubre toda la potencialidad del guiñol como medio artístico con el que contribuir a la concienciación socio-política y al acercamiento de la cultura a las clases más desfavorecidas. De ahí que, como veremos, en los primeros meses de guerra Prieto volviera a cooperar con las Misiones Pedagógicas. Igualmente, aunque más esporádica y puntualmente, a fines del lustro el pintor también colaboró con el Teatro Universitario de La Barraca, fundado por Lorca y Ugarte en 1932.

Poco después de los estrenos del Teatro Español, el sábado 12 de mayo de 1934, en el Hotel Florida, como recogieron $\mathrm{La} \mathrm{Voz} \mathrm{y} \mathrm{Luz}^{47}$, la Federación Universitaria Escolar (FUE) celebró una comida de homenaje al director del Teatro Universitario La Barraca, Federico García Lorca, con motivo de su regreso de Argentina. Ésta estuvo seguida de la representación ofrecida por el poeta granadino del entremés atribuido a Cervantes Los habladores y de una obrita de él mismo, el Retablillo de Don Cristóbal, realizadas en un guiñol construido por Manuel Fontanals e interpretadas por actores de La Barraca, con la colaboración de los muñecos de los que era autor un "artista argentino". Nada se decía aquí, sin embargo, de Miguel Prieto, que no tardaría en poner en escena su guiñol La Tarumba, con esas mismas dos obras y en un nuevo marco. Otros testimonios, no obstante, vinculan su presencia con el acto del Hotel Florida. Según Sáenz de la Calzada, que fue miembro de aquel Teatro Universitario, y otros autores que apoyan su testimonio ${ }^{48}$, sólo una vez se ocupó La Barraca de una representación de los Títeres de la Cachiporra de Lorca, y fue poco después del regreso del poeta de Argentina, en una representación que tuvo lugar en mayo de 1934 en el Hotel Florida y en la que se puso en escena el guiñol El retablillo de don Cristóbal lorquiano. Para la ocasión colaboraron Prieto, que seguramente se ocupó de los decorados interiores; Fontanals, que debió realizar el frontispicio; José Caballero, que era habitual en la escenografía de La Barraca, y Ángel Ferrant, que se encargo de la cabeza de los muñecos, los cuales fueron vestidos con los mismos trajes que se trajo Lorca en la maleta de su estreno bonaerense.

Pero la más destacada aportación de Miguel Prieto al guiñol, con todo, pronto tendría su nombre propio. En el citado testimonio autógrafo de 1950, de hecho, el manchego indicó sobre su colaboración con Lorca y el origen del nombre de La Tarumba (fig. 3) para su guiñol:

Debía ser por el año 1934, cuando un grupo numeroso de amigos nos reuníamos por las tardes en la Cervecería Correos de Madrid y entonces surgió la idea de montar un guiñol literario entre Federico García Lorca, el poeta chileno Pablo Neruda, que entonces era Cónsul General de su país en España, y yo. Los tres estuvimos varios días tratando de buscar nombre para nuestro teatrillo y fue Neruda el que encontró el nombre de La Tarumba, por aquella voz popular que dice "que de tanto hablar uno se vuelve tarumba"49.

guiñol de Misiones primero fue dirigido por Dieste y Ramón Gaya y luego por Miguel Prieto y Serrano Plaja. Como Dieste fue becado por la Junta para Ampliación de Estudios y, entre enero y agosto de 1935, permaneció en Francia, Bélgica e Italia visitando centros teatrales, se ha planteado (AYUSO: Op. cit., p. 56) el que fuera Prieto quien asumiera temporalmente su dirección en este periodo; aunque para entonces, como veremos, éste tenía en funcionamiento $L a$ Tarumba.

47 "Los estudiantes mantienen la actitud del sábado. La FUE proseguirá sus actividades”, La Voz, Madrid, 14-5-1934, p. 3; "Los últimos sucesos escolares. Una nota de la Federación Universitaria Escolar", Luz, Madrid, 14-5-1934, p. 1.

48 Sáenz De La Calzada, Luis: La Barraca. Federico García Lorca y su Teatro Universitario, Madrid, Revista de Occidente, 1976, pp. 105-151; Gibson, Ian: Federico García Lorca. 2. De Nueva York a Fuente Grande (1929-1936), Barcelona, Crítica, [1987], 1998, p. 314; Ayuso: Op. cit., p. 50.

49 Bonet/Brihuega/Perujo: Op. cit., 2007, p. 31. 
Algunos autores que conocieron el momento, como Guillermo de Torre, han insistido en que La Tarumba fue continuación de los Títeres de la Cachiporra ${ }^{50}$, y lo cierto es que entre las iniciativas de Lorca y Prieto existió una gran relación y quizá cierta sucesión, pero también mezcolanza, mutua colaboración y solapamiento. Así, en 1956, intercalando la historia contada por Lorca sobre cómo escribió Los Títeres de la Cachiporra para guiñol en Argentina, el pintor manchego señalaba:

A Federico y a mí nos gustó mucho el título [de La Tarumba] e inmediatamente me puse a construir el tingladillo y a montar las obras teatrales. Lo primero que tome en mis manos para su puesta en escena fue Los Títeres de la Cachiporra, de Lorca. [...] A las pocas semanas tuve yo montado el tinglado con sus escenografías y muñecos y también montada plásticamente la obra, ya terminada y retocada por Federico y un entremés de Cervantes titulado Los habladores. Cuando se corrió la voz por Madrid de la formación del teatrito de guiñol, tuvimos muchas ofertas de locales para su debut. Entre todos los ofrecimientos nosotros seleccionamos el Liceum Club Femenino, que era una institución de mujeres en que figuraban preferentemente las señoras de prohombres de la República Española ${ }^{51}$.

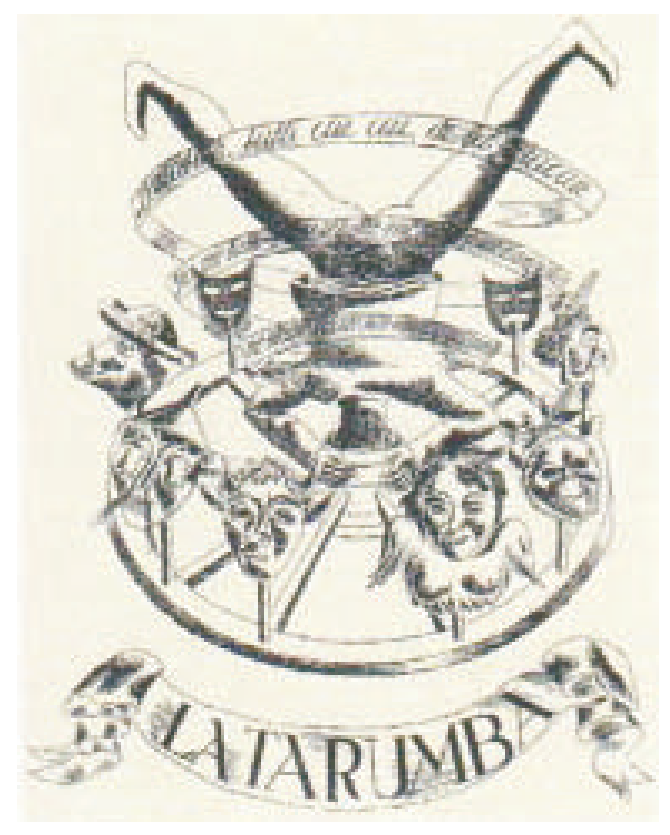

Fig. 3. La Tarumba, ilustración del programa de su primera representación, enero 1935.
Efectivamente, según anunciaba el programa conservado, el debut de La Tarumba se llevó a cabo el 26 de enero de 1935 en el Lyceum Club Femenino, compuesto de dos partes. En la primera, se interpretaron Preludio, de Rodolfo Halffer, y el citado entremés cervantino Los habladores. En la segunda, se representó El retablillo de Don Cristóbal, de García Lorca. Era responsable de los fantoches y decorados Miguel Prieto, y los manejaban él mismo y Gustavo Bertot, mientras el piano corría a cargo de Enrique Casal ${ }^{52}$. Enrique Díez-Canedo, que había asistido al que consideraba su "ensayo general", señaló que se trataba de unos "deliciosos muñecos, cualquiera de los cuales, por ejemplo, la moza del servicio [de Los habladores], bastaría por sí solo para demostrar la pericia de los muñequeros". Y concluía: "La plástica del guiñol 'La Tarumba' es perfecta; su elocución también", aunque veía más problemático el dominio del texto y la improvisación ${ }^{53}$. El éxito hizo que, el sábado 9 de febrero, como anunció La Voz, El Heraldo de Madrid o El Sol ${ }^{54}$, se celebrara en el mismo lugar una segunda representación de dichas obras por el guiñol de Miguel Prieto; esta vez precedida de unas palabras preli-

50 Torre, Guillermo de: Tríptico del sacrificio, Buenos Aires, Losada, 1948, p. 68.

51 Bonet/Brihuega/Perujo: Op. cit., p. 34.

52 Ibidem, p. 34.

53 E. D.-C. (Enrique Díaz-Canedo): "Información teatral. En el Lyceum Club. Un guiñol nuevo: La Tarumba de Miguel Prieto", La Voz, Madrid, 29-1-1935, p. 3.

54 "Otra fiesta en el Lyceum Club", La Voz, Madrid, 7-2-1935, p. 5; "Lyceum Club Femenino", El Heraldo de Madrid, Madrid, 8-2-1935, p. 7; "Escena y bastidores. Lyceum”, El Sol, Madrid, 9-2-1935, p. 2. 
minares de Juan Chabás, ilustraciones musicales para su obra interpretadas por el mismo García Lorca y un preludio musical de Enrique Casal.

No obstante, cuando más popularidad alcanzó La Tarumba fue durante la III Feria del Libro de ese año ${ }^{55}$, celebrada en el Paseo de Recoletos madrileño entre el 5 y 20 de mayo. Durante ella, como avanzó el programa -repetidamente publicado por El Siglo Futuro, La Época, El Heraldo de Madrid, La Voz, El Sol o La Libertad ${ }^{56}$, se ejecutaron cuatro representaciones por el guiñol de Miguel Prieto instalado en el tablado de la Plaza de Colón. La primera fue el día 5, con el Retablillo de Don Cristóbal de Lorca; la segunda el domingo 12, con el Entremés del mancebo que casó con mujer brava, que escenificaba el cuento del Conde Lucanor, adaptado por Alejandro Casona; la tercera el día 16, con Los habladores atribuidos a Cervantes y, finalmente, la cuarta y última el domingo 19, con el Entremés del dragoncillo de Calderón de la Barca. Además, el éxito de algunas piezas y la afluencia de público, obligó a alterar y reponer algunas piezas, como el Retablillo de Lorca, representado también el día $12^{57}$. Sin embargo, parece ser que, por problemas de censura en estos restrictivos años del "Bienio Negro", La Tarumba no pudo volver a presentarse en público hasta la llegada del Frente Popular en febrero de $1936^{58}$, momento en el que hizo una nueva representación, de gran formato, en el Teatro Español ${ }^{59}$.

Prieto, por otro lado, además de la labor que desarrolló con su guiñol entre 1934 y 1936, de cuyas características plásticas tan pocas descripciones tenemos, continuó colaborando con sus ilustraciones en Octubre y otras revistas, tanto madrileñas - Ahora, Diablo Mundo, El Tiempo Presente o Arte- como de otros lugares -la malagueña Sur o la valenciana Nueva Cultura-, cada vez con un carácter más implicadamente realista. Su conexión con el mundo creativo y literario más comprometido, también se hizo muy evidente, como nos ha narrado Josep Renau ${ }^{60}$ respecto al nacimiento de Nueva Cultura o como muestra su presencia entre la inquieta intelectualidad madrileña que, el 9 de febrero de 1936, ofreciera una comida-homenaje a Rafael Alberti y María Teresa León en el Café Nacional, tras su viaje por Europa y América ${ }^{61}$. Entre los asistentes se hallaba también Ramón J. Sender, con quien Miguel Prieto, poco antes de que estallara la guerra, daría el salto de la escenografía pensada para un guiñol, a la pensada para un teatro.

Se trató del drama en un acto El secreto, que Sender había basado en los pasados años de luchas sociales habidas en Barcelona y cuya primera representación, al igual que el estreno del decorado del almodovense, ya se estaba anunciando a finales de abrili ${ }^{62}$. Luego, la obra fue estrenada en el Teatro Cervantes de Madrid el 19 de mayo de 1936, con la escenografía de Miguel

55 Parece ser que, ya en el mes de marzo, el mismo Prieto y su esposa, Angelita Ruiz, visitaron en la Agrupación de Editores Españoles a Rafael Giménez Siles, que por entonces se dedicaba a organizar la Feria y es quien relata el hecho (Retazos de vida de un obstinado aprendiz de editor, librero e impresor. Memorias por entregas (1. ${ }^{a}$ ), México, ed. del autor-Imp. Azteca, 1984, p. 60), y le informaron de que tenían organizado un modesto guiñol accionado por ellos mismos, La Tarumba, solicitándole participar en la Feria para poder mantenerlo, y que éste les contrató cuatro representaciones.

56 "Agrupación de Editores Españoles. III. ${ }^{a}$ Feria del Libro de Madrid", El Siglo Futuro, Madrid, 27-4-1935 y 4 5-1935, p. 27; La Época, Madrid, 4-5-1935, p. 5; El Heraldo de Madrid, Madrid, 4-5-1935, p. 12; La Voz, Madrid, 45-1935, p. 5; El Sol, Madrid, 5-5-1935, p. 2; La Libertad, Madrid, 5-5-1935, p. 7.

57 "La Feria del Libro", La Época Madrid, 13-5-1935, p. 3; "Feria del Libro", El Heraldo de Madrid, Madrid, 135-1935, p. 13.

58 GonzÁlez TuÑón, Raúl: "La Tarumba (Los títeres al servicio de la guerra)", Ahora. Diario Gráfico, Madrid, 12-5-1937, pp. 7-8.

59 Bonet/Brihuega/Perujo: Op. cit., pp. 76-77.

${ }^{60}$ Renau, Josep: "Notas al margen de Nueva Cultura", Nueva Cultura, Vaduz, Liechtenstein, Topos Verlag AG, 1977, pp. 12-24.

61 "Homenaje popular a María Teresa León y Rafael Alberti”, La Libertad, Madrid, 8-2-1936, p. 9.

62 "Escena y bastidores", El Sol, Madrid, 29-4-1936, p. 2. 
Prieto e interpretada por el grupo de teatro del Círculo Popular Cervantes. La representación estuvo precedida tanto de una conferencia de Sender, titulada "Sobre el nuevo teatro" y referida a las nuevas fórmulas del teatro proletario, como de la interpretación por Agapito Marazuela (otro asiduo del Fomento de las Artes) de obras folclóricas recogidas por él en Castilla, acompañándose de viejos instrumentos típicos. En cuanto a la escenografía de la obra, en $\mathrm{El} \mathrm{Sol}^{63}$ se dijo que había sido "realizada con insuperable acierto y un fino sentido por el joven pintor Miguel Prieto" y que estaba "muy a tono" con las escenas de este drama ambientado en las recientes luchas sociales barcelonesas, el cual fue interpretado por Miguel Serrano, Vicente Martínez, Gerardo García y Pedro Gramage ${ }^{64}$. Pero lo cierto es que, la obra del autor aragonés, ya había sido escenificada, quizá como preestreno, durante la gira previa que éste hizo por Asturias. Entonces, el drama El secreto, también precedido de la conferencia de Sender "El nuevo teatro", se había representado, por ejemplo, el 2 de abril en el Teatro Robledo de Gijón, interpretado por el grupo de Ensayos Teatrales del Ateneo gijonés ${ }^{65}$.

No sabemos, sin embargo, si en tales funciones previas a la de Madrid se contó ya con la escenografía de Miguel Prieto, como tampoco estamos seguros de que sus decorados siguieran utilizándose en las que nuevamente tuvo la obra una vez iniciado el conflicto bélico. En cualquier caso, tenemos noticia de que, durante esos tiempos de guerra, El secreto de Sender no sólo comenzó a viajar con la compañía Meliá-Cibrián, que lo llevó en su repertorio y lo representó el 9 de septiembre de 1936 en la Sala Capitol de Albacete, durante las ferias de la ciudad ${ }^{66}$, sino que también nuevamente empezó a interpretarse en Madrid, ahora en el Teatro Popular, desde el 24 de septiembre, según registra la cartelera ${ }^{67}$. Sobre este drama en un acto, cuyo reestreno en el Popular no fue muy publicitado, se destacó, sin embargo, su papel orientador del futuro teatro, la intensidad dramática de su tema y la sobresaliente interpretación protagonista del actor Monsell, pero su decorado no se consideró acorde con el ambiente de la pieza y la actualización teatral ${ }^{68}$. La obra -sobre la que se indicó que a diario venía "mereciendo el aplauso entusiasta y el elogio sincero del público"69- siguió manteniéndose en la cartelera madrileña durante las primeras semanas de octubre; mientras la compañía de Pepita Meliá y Benito Cibrián la representaban en varios lugares, como en la concurrida y exitosa función que realizaron el 3 de noviembre de 1936 en Alicante, a beneficio de las familias de los combatientes del 5. ${ }^{\circ}$ Regimiento y los marinos del Transvaal ${ }^{70}$.

63 "Escena y bastidores. Estreno del drama de Ramón J. Sender El secreto", El Sol, Madrid, 19-5-1936, p. 2.

${ }^{64}$ E. L.: "Escena y bastidores. Cervantes. Segunda reunión del grupo de teatro de la Biblioteca y Círculo Popular Cervantes", El Sol, Madrid, 21-5-1936, p. 2.

65 "Una conferencia de Ramón J. Sender en Gijón", El Sol, Madrid, 3-4-1936, p. 5.

66 "La feria de Albacete", $A b c$, Madrid, 10-9-1936, p. 15.

67 “Espectáculos para hoy”, La Libertad, Madrid, 23-9-1936, p. 5; Abc, 24-9-1936, p. 14. La inauguración en el Popular estuvo prevista para el 23 de septiembre, junto al estreno de la obra original del actor-autor Luis Mussot titulada iNo pasarán!, pero un fuerte ataque gripal de éste, obligó a suspenderlo y a comenzar a representar desde el día 24 sólo El secreto, a la espera de la recuperación de Mussot (Abc, 10-9-1936, p. 10).

${ }^{68}$ Se dijo (SAM: "Informaciones y noticias teatrales en Madrid. Popular: El secreto", Abc, Madrid, 25-9-1936, p. 14) que esta producción podía "marcar el camino a seguir en el teatro del porvenir, que ha de ser revolucionario en la forma -atuendo, decorado, juego de luces, utilización de masas...- y en el fondo, orientador hacia nuevas rutas ideológicas y rememorador de los antiguos senderos que nunca más se han de recorrer". También se destacó como un "episodio intensamente dramático, granguiñolesco casi, de los años bochornosos del pistolerismo barcelonés, [que] ha servido a Sender para trazar varias escenas sobrias, vigorosas, con personajes perfilados de auténtica humanidad". La interpretación estaba "muy a tono con el cuadro", aunque el decorado no resultaba "nada acorde con el ambiente que trata de reproducir ni con las exigencias de un espectáculo actual".

69 "Escena y bastidores. Teatro Popular", El Sol, Madrid, 27-9-1936, p. 3.

70 "Informaciones y noticias teatrales. Beneficio en Alicante", $A b c$, Madrid, 4-11-1936, p. 14-15. 


\section{Arte, escena y compromiso activo en los tiempos de guerra}

Iniciado el conflicto bélico, no tardó en nacer la Alianza de Intelectuales Antifascistas para la Defensa de la Cultura (AIDC), de la que Prieto fue socio fundador y secretario de su Sección de Artes Plásticas, así como fue director artístico de su principal órgano de expresión, la revista $E l$ Mono Azul, y no dudó en firmar, junto a otros importes intelectuales y creadores, su llamamiento de julio y su manifiesto de noviembre ${ }^{71}$. También tomó parte en otras publicaciones periódicas, como Ahora, Índice o Acero, y, en paralelo a su trabajó en el Taller de Artes Plásticas de la AIDC, formó parte -junto a Ángel Ferrant y Gabriel García Maroto- de la Comisión encargada de reorganizar la enseñanza de la Escuela de Bellas Artes de Madrid, creada por el Ministerio de Instrucción Pública (MIP) y su Dirección General de Bellas Artes (DGBA). De esta manera, con el impulso tanto de la Alianza como del MIP, Prieto no sólo colaboró en varios proyectos pedagógicos sobre las escuelas de Bellas Artes, Artes Gráficas y Artes y Oficios, sino que, entre otras actuaciones, también realizó diferentes carteles, ilustraciones y ediciones de folletos y libros (como, entre los primeros, el conocido cartel ;Milicianos!... Antes morir que retroceder, que editó la citada DGBA). Llama la atención, respecto a estas actuaciones, su temprana intervención, en julio de 1936, en el proyecto de creación de un Parque Infantil y un Hogar Escuela, encargado por el Socorro Rojo Internacional, cuyas obras se encomendaron al arquitecto Manuel Sánchez Arcas, en unión con sus colegas Rafael Bergamín, José María Arrillaga y Martín Domínguez; con la asesoría artística, para el teatro al aire libre, el club y el cine pensados construir, de Rafael Alberti, Miguel Prieto y Eduardo Ugarte ${ }^{72}$. En la misma línea, posiblemente también se dio la destacada colaboración del manchego y su guiñol en algunos espectáculos benéficos de primera hora, como el festival que, a favor de las Residencias y Guarderías Infantiles y patrocinado por el teatro y coro de las Misiones Pedagógicas, se celebró el 22 de agosto de ese año en el Teatro Español ${ }^{73}$; el cual tuvo su momento culminante con tres representaciones de guiñol: el entremés El dragoncillo de Calderón de la Barca, que exhibía "un aire grotesco muy cabal", El enamorado y la muerte de Alberti y El falso faquir de Dieste, estas dos últimas de "perfecta" escenificación ${ }^{74}$.

En cuanto al mundo de la escena, Prieto entraba en el momento bélico con una doble experiencia, que se hacía conjugable: la más consolidada de su aplaudido guiñol y la que le aportaba su reciente colaboración escenográfica con Sender. El manchego puso de inmediato su guiñol al servicio de la Alianza, alcanzando amplios resultados ya en su primer año, como

71 "Manifiesto de la Alianza de Escritores Antifascistas para la Defensa de la Cultura" (encabezado por Emiliano Barral), La Voz, Madrid, 30-7-1936, p. 3; "A los intelectuales antifascistas del mundo entero" (manifiesto encabezado por José Bergamín), El Sol, Madrid, 19-11-1936, p. 2; "Un manifiesto de los intelectuales antifascistas", Abc, Madrid, 20-11-1936, p. 6

72 VegA, Esteban: "En favor de los niños huérfanos. Parque Infantil y Hogar Escuela del Socorro Rojo Internacional", La Voz, Madrid, 30-7-1936, p. 6; "Parque Infantil y Hogar Escuela", Abc, Madrid, 31-7-1936, p. 24.

73 "Festivales. A beneficio de las Guarderías Infantiles", El Sol, Madrid, 20-8-1936, p. 3; "A beneficio de las víctimas que lucha por la República. En el Teatro Español", La Libertad, Madrid, 21-8-1936, p. 5; "Funciones benéficas", $A b c$, Madrid, 21-8-1936, p. 13.

74 SAM: "Informaciones y noticias teatrales en Madrid. Español: Beneficio de las Guarderías infantiles", $A b c$, Madrid, 23-8-1936, p. 13. La crónica no cita a Prieto, pero ya vimos que éste había representado El dragoncillo con La Tarumba en mayo de 1935, durante la III Feria del Libro. También le interesó El enamorado y la muerte de Alberti, obra sobre la que su archivo personal incluso guarda unos apuntes con un planteamiento escénico suyo (ilustración Bonet/Brihuega/Perujo: Op. cit., p. 65). En cuanto a El falso faquir, Dieste afirmó en los años ochenta que lo había representado Miguel Prieto en el Teatro Español, en un guiñol semejante al de Misiones, fabricado por el manchego antes de la guerra, y que, aunque el no pudo asistir a la representación, la impresión que sacaron Serrano Plaja y Alberti fue muy favorable (Ayuso, Op. cit., pp. 56-57). Todo ello induce a pensar que Prieto se encargó de las tres representaciones. 


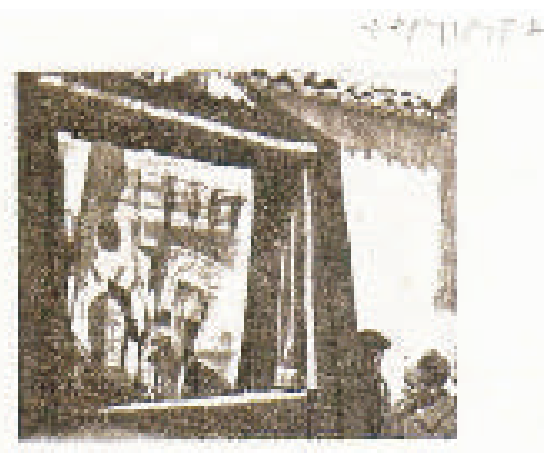

IOS SAIVADORES

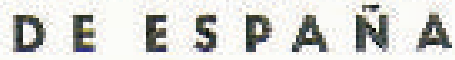

TAUSA SATIRICA DATA GUIBOL DOR

R A F A E L A I B E R T I

Fig. 4. Rafael Alberti: Salvadores de España, 1936. La llave, de Sender, drama en un acto sobre la revolución de Asturias; Al amanecer, de Dieste, sobre la cursilería burguesa, y sobre todo Los salvadores de España, de Alberti (fig. 4), cuyo éxito y decorados describía así el diario:

... es sin duda de las tres obras estrenadas ayer en el Español la más hermosa y mejor lograda. Ha preferido Alberti extremar los caracteres caricaturescos de la farsa más que "pintar" tales caracteres, jugar con fantoches antes que con personajes. La comparsa moros, falangistas, italianos, alemanes, etcétera- de los "salvadores" de España desfila ante el público. Allí hablan y gesticulan cada uno en su jerga -imitada por Alberti con vocablos españoles de manera graciosísima- y se emborrachan de patriotismo para traicionar a la patria.

El estupendo decorado de Miguel Prieto contribuyó en gran medida al gran éxito alcanzado por esta farsa. El tono de estampa de vivos colores de la obra de Alberti encuentra justa correspondencia en la decoración ideada por el pintor Prieto, que se acredita como uno de nuestro primeros escenógrafos con esta obra.

Espantaleón, el estupendo obispo: Arbó, Fuentes y demás intérpretes de Los salvadores de España fueron asimismo muy aplaudidos.

Esta "ensaladilla de Alberti", como la llamó el crítico de $L a V o z^{79}$, que vio en ella "una pequeña maravilla del humor”, no fue la única actuación importante de Prieto para Nueva Escena,

75 Zambrano, María: "La Alianza de Intelectuales Antifascistas”, Tierra Firme, n. o 3-4, Madrid, 1936 , p. 611.

76 Aznar, Manuel: República literaria y revolución (1920-1939), 2 vol., Sevilla, Renacimiento, 2010, p. 442.

77 "La inauguración del Español", $A b c$, Madrid, 9-10-1936, p. 15.

78 S.: "Escena y bastidores. Teatro Español. Presentación de Nueva Escena, compañía de la Alianza de Intelectuales Antifascistas", El Sol, Madrid, 21-10-1936, p. 3.

79 J.L.S.: "El Teatro. Tres estrenos en el Español”, La Voz, Madrid, 21-10-1936, p. 3. 
compañía a la que, entre otros artistas escenógrafos, también pertenecieron Ramón Gaya, Arturo Souto, Eduardo Vicente y, sobre todo, Santiago Ontañón, quienes se ocuparon de los figurines y decorados, especialmente del Teatro Español que había cedido el Ayuntamiento a Nueva Escena. Así, a finales del mes de octubre de aquel 1936, se inauguró en el saloncillo de este teatro una exposición de bocetos, organizada por Nueva Escena, donde se presentó a su cuerpo de escenógrafos, integrado tanto por Miguel Prieto como por todos los citados. Se exhibía, fundamentalmente, escenografía, figurines y piezas de las siguientes obras ya representadas: La llave de Sender, Los salvadores de España de Alberti y otras que se pensaba representar: una de Bergamín y otra de Synge, El gato de silex de Dieste, Tamar de Tirso y el Sombrero de tres picos. También figuraban bocetos de Burgos para La tienda de los gestos, de Lope, y otros para El dragoncillo de Calderón de la Barca; mientras Juan Antonio Morales exhibía dos trabajos suyos con fina entonación y ritmo. "El decorado -añadía una crónica- no ha de limitarse a un simple adorno; su misión es, desde luego, más alta. Nueva Escena se afana por que exista una compenetración profunda entre la obra teatral y el decorado, siendo este último un personaje más, vital, y no mero tapiz de fondo" 80 . Paralelamente, otros diarios y revistas, como El Sol o Crónica ${ }^{81}$, continuaron insistieron en estos mismos hechos que reflejaba la exposición y en la labor que estaba llevando a cabo la Sección de Artes Plásticas de la Alianza, a cargo de Miguel Prieto y otros artistas, y en cuyo seno se realizaban los decorados de Nueva Escena exhibidos en el Teatro Español.

Trasladado a Valencia en noviembre de 1936, Miguel Prieto siguió colaborando allí con la homónima Alianza valenciana. Residió en su local social de la calle Trinquete de Caballeros $9^{82}$ y fue responsable de su órgano de expresión -la revista El Buque Rojo, aparecida el 3 de diciembre- junto a los pintores Arturo Souto, Antonio Rodríguez Luna y Ramón Gaya y los escritores Juan Gil-Albert, Rafael Dieste y Antonio Sánchez Barbudo ${ }^{83}$; así como también participó en la edición e ilustración de otras revistas -como Línea, Vanguardia o Nueva Cultura $(A I D C)$ - y en la realización de carteles. Frecuentó a la intelectualidad y las tertulias de los cafés $^{84} \mathrm{y}$, al mismo tiempo, no se olvidó de la escenografía y el guiñol. De suerte que, el 30 de diciembre de ese mismo año, escenificó con su guiñol de propaganda, en el teatro Olimpia de Valencia, dentro de un acto del Comisariado de Guerra, la Parodia de Queipo y Salvadores de España de Alberti ${ }^{85}$.

Además, creadas en febrero de 1937 las Milicias de la Cultura, Miguel Prieto, convertido en miembro de las mismas, anduvo desde entonces llevando a los frentes su teatrillo de guiñol La Tarumba con el Comisariado General del Ministerio de Guerra/Defensa. De hecho, aparte de la existencia de otras imágenes sobre estas actuaciones en el frente, a finales de marzo de ese año,

\footnotetext{
80 "El arte y la República. Una exposición de Nueva Escena en el Teatro Español”, La Voz, Madrid, 31-10-1936, p. 3.

81 "Una Exposición de Nueva Escena", El Sol, Madrid, 2-11-1936, p. 2; R.M.G. (Rafael Martínez Gandía): "La Alianza de Intelectuales Antifascistas para la Defensa de la Cultura”, Crónica, Madrid, 1-11-1936, p. 3.

82 Pérez CONTEl: Op. cit., p. 253.

83 AzNAR, Manuel: "L'Aliança d'Intel·lectuals per a Defensa de la Cultura de València (AIDCV)", en AzNAR, M. (ed.): València, capital cultural de la República (1936-1937), Vol. 1, Valencia, Consell Valencià de Cultura, 2007, p. 44.

${ }^{84}$ Incluso alguna novela sobre esos días (SALAZAR ChAPela, Esteban: En aquella Valencia, [1. a ed. 1995], Sevilla, Renacimiento, 2001, pp. 193-200) le hace personaje y contertulio de la peña del café Ideal Room, junto al arquitecto Sánchez Arcas, el doctor Palomino y otros.

85 "Acto de propaganda del Comisariado de Guerra", La Libertad, Madrid, 31-12-1936, p. 8; "Gran festival de propaganda. Un discurso de Álvarez del Vayo”, Abc, Madrid, 31-12-1936, p. 5-6.
} 


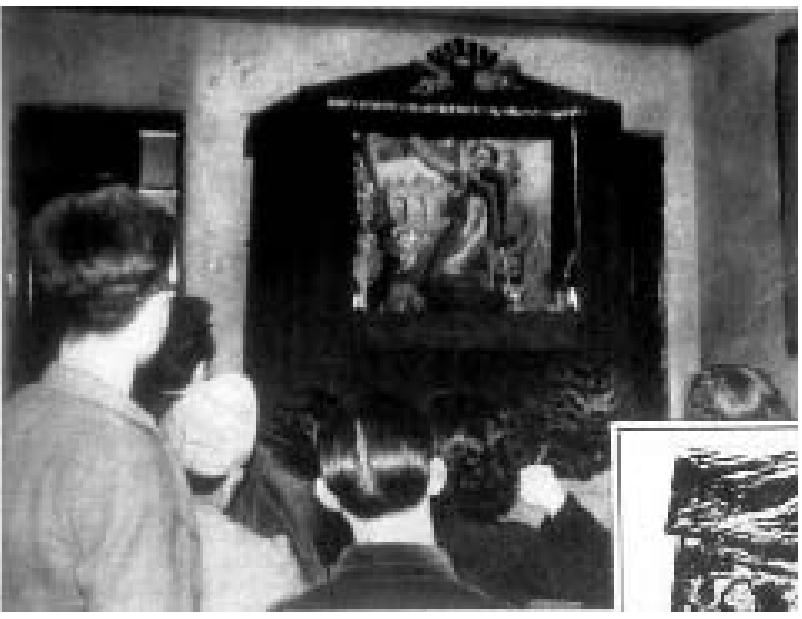

Fig. 5. Representación de La Tarumba en las Milicias de la Cultura (Mundo Gráfico, n. ${ }^{\circ}$ 1325, 24-4-1937).

Mundo Gráfico ${ }^{86}$ captaba en una foto (fig. 5) una de las representaciones de La Tarumba -el guiñol satírico que cumplía tan "buena labor en la vanguardia y la retaguardia"-, la cual era comentada junto a la labor impulsada por el comisario y fundador de la Milicias de la Cultura, el pintor manchego Gabriel García Maroto. Igualmente, en mayo de ese año, un artículo de Raúl González Tuñón en la revista $\operatorname{Ahora}^{87}$ (fig. 6), describe e ilustra la labor de La Tarumba en el frente, auspiciada por el Subcomisariado de Propaganda, del Comisariado General de Guerra; una tarea en la que Miguel Prieto se ve acompañado por su esposa, los jóvenes poetas Felipe Camarero Ruanova, Pérez Infante ${ }^{88}$ y, más esporádicamente, Emilio Prados. Asimismo el artículo comenta alguna de las piezas representadas en los frentes, hospitales, fábricas escuelas o aldeas: Retablillo de Don Cristóbal, Los salvadores de España, Lidia de Mola en Madrid, Borracheras de Queipo de Llano, Hitler, Mussolini, Tanques y aviones de cartón y algunas farsas cervantinas. Igualmente, a finales de julio, una foto de Yubero y Benítez en $A b c^{89}$ sobre el guiñol de Prieto en el frente, ilustraba sobre las funciones que se preparaban a los soldados del Ejército Popular al final de la jornada.

En cuanto al repertorio de este "guiñol satírico" La Tarumba, también existe algún cartel de la época, como el conservado en el Centro Documental de la Memoria Histórica (CDMH) de Salamanca (fig. 7), editado por dicho Subcomisariado y dirigido a los soldados republicanos, que recoge las siguientes obras: Lidia de Mola en Madrid, Radio Sevilla, Retablillo de Don Cristóbal y Los salvadores de España $a^{90}$, respectivamente de Antonio Aparicio, Alberti, Lorca y Alberti. Por otro lado, también podemos tener una idea bastante precisa de las funciones de guiñol realizadas por las Milicias de la Cultura, pues si en un balance referido a su actividad durante el año 1937, $A b c^{91}$ daba la cifra de 78 representaciones de guiñol ante los soldados, Mi Revista ${ }^{92}$ contabilizaba 86 funciones hasta mayo de 1938, esto es durante el primer año largo de vida de las Milicias de la Cultura, y a buen seguro que ello se debió al impulso y diligente actuación del manchego (fig. 8).

${ }^{86}$ A.O.S. (Antonio Otero Seco): "La labor heroica y abnegada de los comisarios de guerra. El teatro, la poesía y la propaganda sanitaria en las trincheras", Mundo Gráfico, n. ${ }^{\circ} 1325$, Madrid, 24-3-1937, p. 6.

87 GONZALÉZ TuÑón: Op. cit., 12-5-1937, pp. 7-8.

88 Altolaguirre, Manuel: "Nuestro Teatro", Hora de España, n. ${ }^{\circ}$ 9, Valencia, Septiembre 1937, pp. 29-30.

89 "Otro plan fascista que fracasa", $A b c$, Madrid, 28-7-1937, p. 2.

90 "El guiñol satírico La Tarumba", Valencia, Subcomisarido de Propaganda (Imprenta José Pascual), c. 19371938. Cartel 64,5 x 44,5 cm. (PS-Carteles, 711, CDMH, Salamanca).

91 "La labor de las Milicias de la Cultura", $A b c$, Madrid, 30-1-1938, p. 3.

92 "Milicias de la Cultura. Los que preparan el ejército de la reconstrucción de España...", Mi Revista, n. ${ }^{\circ}$ 44-45, Barcelona, 15-7-1938, p. 94. 


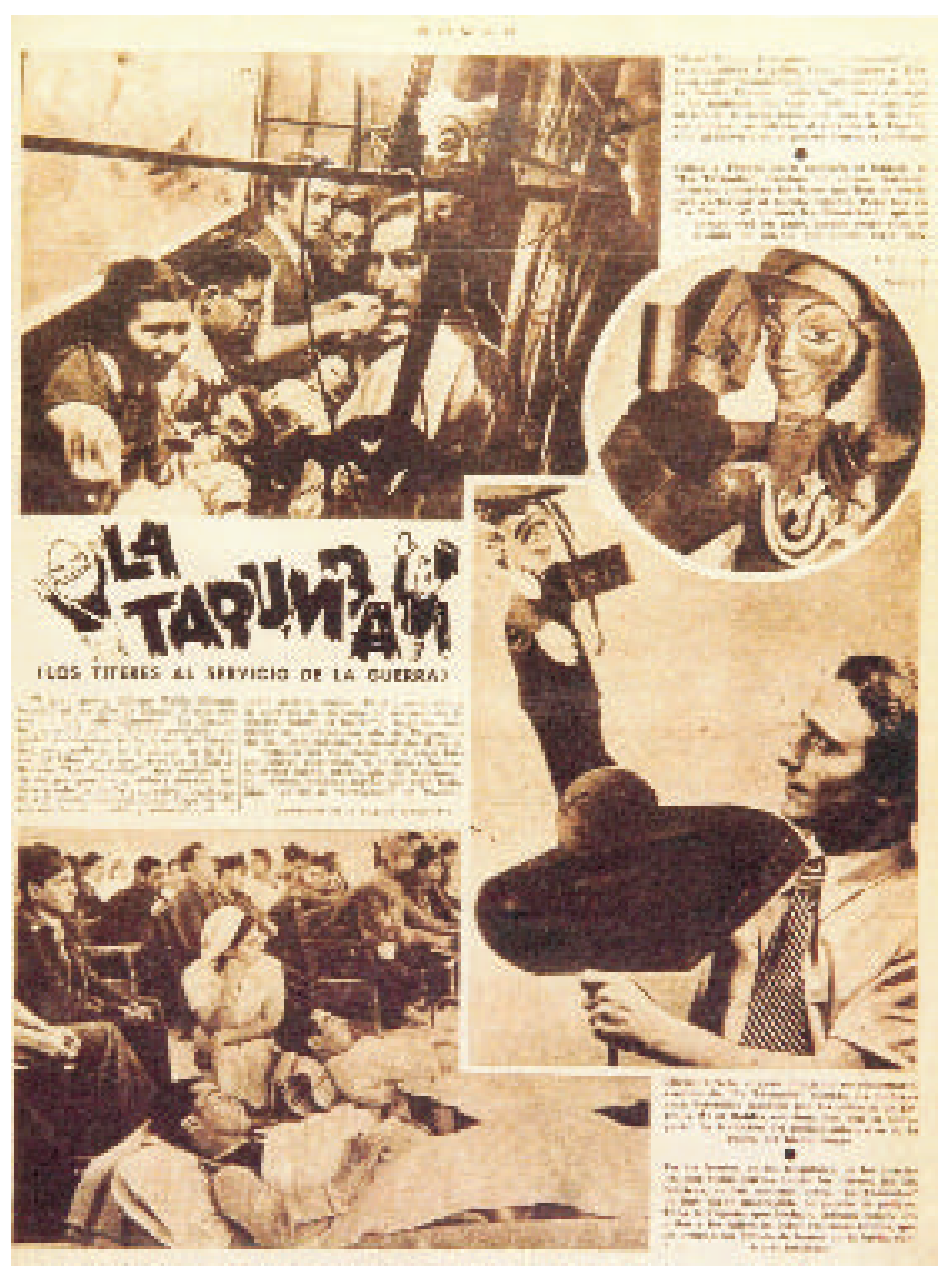

Fig. 6. Raúl González Tuñón: “La Tarumba”, Ahora, Madrid 12-5-1937, p. 7.

Su compromiso junto a la intelectualidad también continuó en paralelo. De forma que será uno de los firmantes de la famosa "Ponencia colectiva" leída por Arturo Serrano Plaja en el II Congreso Internacional de Escritores para la Defensa de la Cultura, inaugurado el 3 de julio de 1937 en Valencia, en la cual se abogaba por el arte comprometido, aunque distante del arte propagandístico y del realismo socialista. Al mismo tiempo, junto a otros creadores, tomaba parte en el álbum colectivo, dirigido por Gabriel García Maroto, Los dibujantes en la guerra de Espa$\tilde{n} a$ y en el posterior Álbum de Homenaje al General Miaja; además de ilustrar libros como el Llanto en sangre de Emilio Prados - tan elogiado por Altolaguirre ${ }^{93}$ - y el Romancero general de la guerra de España, dedicado a García Lorca.

Sin embargo, será su labor como escenógrafo la que más se oficialice, especialmente a raíz de la creación el 22 de agosto de 1937 del Consejo Central del Teatro (CCT), dependiente de la

93 Altolaguirre, Manuel: "La poesía, en guerra", $A b c$, Madrid, 3-8-1937, p. 11. 


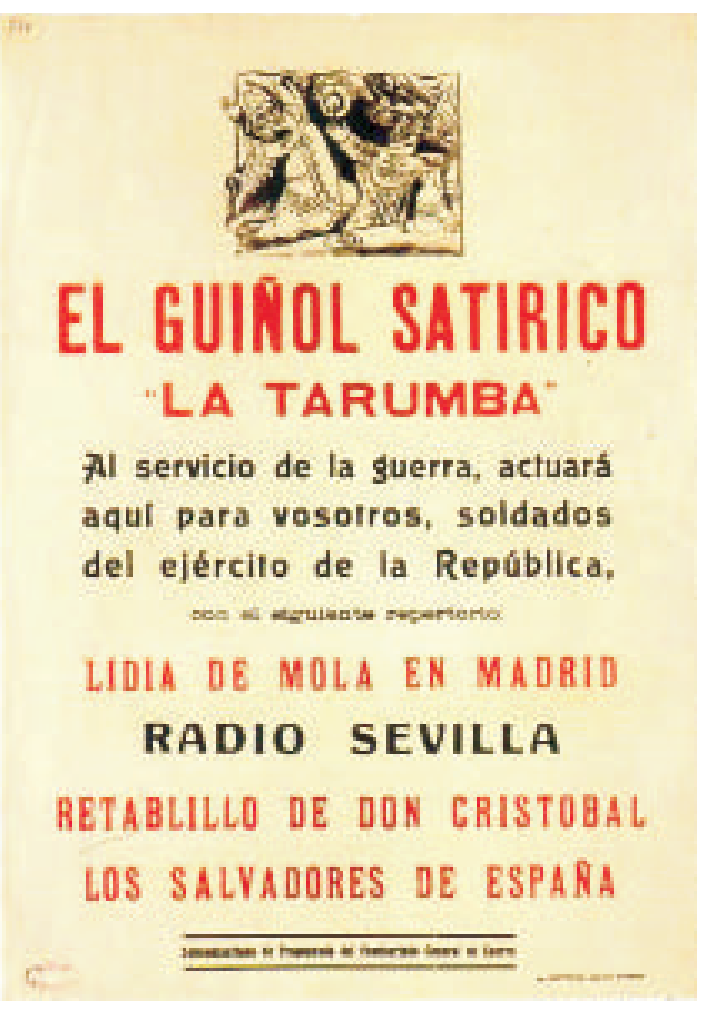

Fig. 7. Cartel-programa de "La Tarumba", Valencia, SubProp, 1937-1939 (CDMH).
DGBA del MIP ${ }^{94}$, del cual pronto sería nombrado vocal. No obstante, antes de producirse tal nombramiento, entre finales de agosto y septiembre de 1937, posiblemente para potenciar su conocimiento sobre la escenografía soviética, Prieto viajó a la URSS con una delegación oficial de profesionales con objeto de asistir a sus famosos festivales anuales de teatro. Éstos se venían celebrando desde 1933 y fueron muchos los creadores que viajaron a verlos al país con fines formativos, como los españoles Alberti, María Teresa León y Maruja Mallo o el mexicano Alfredo Gómez de la Vega, que dejó escrito a su vuelta un elocuente relato sobre el dinamismo, papel formativo y capacidad de atracción de estas convocatorias ${ }^{95}$

Componían la expedición Cipriano Rivas Cherif, que actuaba como su responsable, la actriz Gloria Álvarez Santullano, el poeta Miguel Hernández, el director del Teatro Popular Tribuna de Madrid Francisco Martínez Allende y Miguel Prieto, todos ellos -salvo el poeta y la actriz- futuros vocales del CCT. Salieron de Valencia el 29 de agosto, el 30 ya estaban en París y el 1 de septiembre en Estocolmo. Su paso por la capital gala, donde les esperaban el arquitecto Luis Lacasa, el escultor Alberto Sánchez y el escritor José Bergamín, permitió al almodovense conocer el Pabellón Español de la Exposición Internacional que allí se celebraba y en el que, al lado de grandes artistas como Picasso, Miró, Julio González, Calder, Alberto, Josep Renau y otros, se exponían cinco dibujos suyos a pluma. Aunque el destino principal era la Unión Soviética y sus festivales de teatro (fig. 9), experiencia sobre, la que ya en el exilio mexicano, pronunció una conferencia en noviembre de $1942^{96}$ en la que dijo:

Permanecí en este país un mes, que casi dediqué por entero al estudio del teatro en las ciudades de Moscú, Leningrado, Kiev, Rostov y Karkov. Asistí diariamente, cuando menos a una función teatral y, por las mañanas, a las diferentes escuelas teatrales, conservatorios, academias de danza y ensayos de obras en preparación. Y durante este período de tiempo pude ver representaciones en los teatros dramáticos más importantes, la ópera y el ballet de Moscú y Leningrado, teatro para niños, opereta, vodevil, teatro de

94 Decreto del MIPS de 22-8-1937, Gaceta de la República, n. ${ }^{\circ} 236$, Valencia, 24-8-1937, p. 769.

95 Gómez De La Vega, Alfredo: El teatro en la U.R.S.S., México D.F., México Nuevo, 1938, p. 20.

${ }^{96}$ Se tituló "El teatro" y tuvo lugar el 18 de noviembre en la Sala Shiefer de la Sociedad de Amigos de la URSS en la capital mexicana. La disertación formaba parte de un ciclo -completado ese mismo día con las respectivamente dedicadas por Otto Mayer-Sierra y Josep Renau a la música y las artes plásticas- con el que se pretendía, como indicó alguna reseña (A.A.E. [Antonio Acevedo Escobedo]: “Anuncios y presencias", Letras de México, n. ${ }^{\circ} 22$, México, 1510-1942, p. 6), dar a conocer las actitudes del pueblo ruso ante la situación de guerra.

Arch. esp. arte, LXXXIV, 336, OCTUBRE-DICIEMBRE 2011, 355-378, ISSN: 0004-0428 


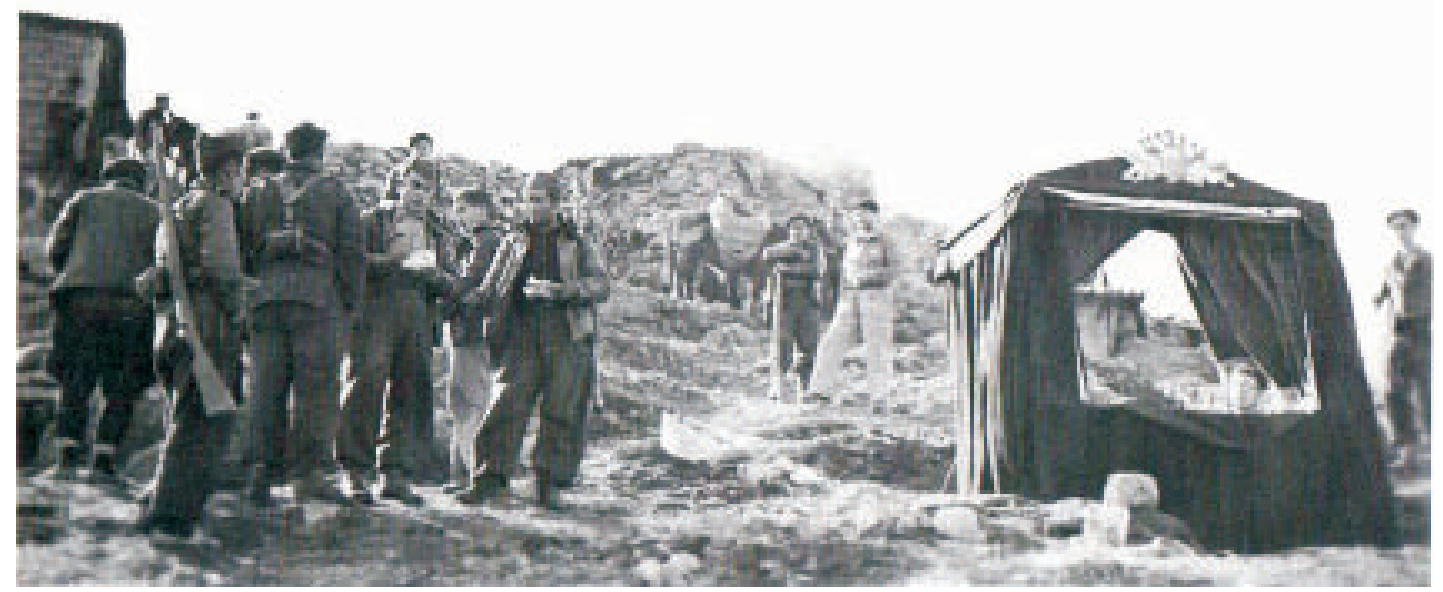

Fig. 8. Guiñol La Tarumba en el frente de guerra, c. 1938 (R. de Estudiantes).

muñecos y, en fin, toda esa maravillosa diversidad de géneros y estilos que forman el inmenso panorama del teatro en la URSS ${ }^{97}$.

Ya de regreso con esta experiencia, las órdenes del MIP de 13 y 15 de octubre ${ }^{98}$ nombraron a los miembros efectivos del CCT, que quedó compuesto por un presidente (Josep Renau, director general de Bellas Artes), un vicepresidente primero (Antonio Machado), un vicepresidente segundo (María Teresa León), un secretario (Max Aub) y diez vocales (Jacinto Benavente, Margarita Xirgu, Enrique Díez-Canedo, Cipriano Rivas Cherif, Rafael Alberti, Alejandro Casona, Manuel González, Francisco Martínez Allende, Enrique Casal y Miguel Prieto). Este hecho dio mayor presencia y relevancia a la labor del almodovense, quien también, ya con el Gobierno en Barcelona y a propuesta del CCT, verá como el 14 de diciembre se creaban las "Guerrillas del Teatro" -para actuar "allí donde quiera que haya o pueda congregarse un auditorio"- y se abría un concurso para dotarlas de un repertorio de representaciones ${ }^{99}$. El 6 de enero de 1938 se creaba la Comisión del Teatro de los Niños, órgano consultivo y asesor del CCT, integrado por Jacinto Benavente (presidente), María Luz Morales (vicepresidente) y los vocales Elena Fortuny, Magda Donato, Esperanza González y Sal-

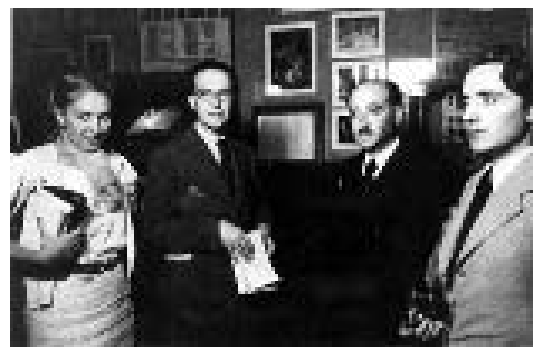

Fig. 9. Gloria Álvarez Santullano, Rivas Cherif, un funcionario soviético y Miguel Prieto en Moscú, septiembre 1937.

\footnotetext{
97 Bonet/Brihuega/Perujo: Op. cit., pp. 37-38.

98 Órdenes del MIPS de 13-10-1937 y 15-10-1937, Gaceta de la República, n. ${ }^{\circ} 287$ y 292, Valencia, 14-10-1937 y 19-10-1937, pp. 162 y 243 respectivamente.

${ }^{99}$ Orden del MIPS de 14-12-1937, Gaceta de la República, n. ${ }^{\circ} 357$, Barcelona, 23-12-1937, p. 1387.
} 
vador Bartolozzi ${ }^{100}$. No obstante, hasta el 2 de marzo ${ }^{101}$, el MIP no dio unas normas concretas, un presupuesto y unos responsables para el claro desenvolvimiento de las "Guerrillas del Teatro y el Guiñol", que quedaban "en vías de estreno". Esas normas convertían oficialmente en responsables de las "Guerrillas" a Martínez Allende y del "Guiñol" a Miguel Prieto, percibiendo cada uno, con efectos retroactivos desde enero, una subvención mensual de 1000 pesetas.

Prieto, con todo, ya disponía desde 1937 de un carnet expedido por el Comisariado General de Guerra, que certificaba que prestaba sus servicios en él como "Responsable del Guiñol". En 1938, al igual que el Gobierno republicano, se había radicado en Barcelona, desde donde seguiría los designios del Ejército Popular del Ebro. Sería nombrado Comisario de Propaganda y Prensa del mismo, para el que también realizó algunos folletos técnicos. El 22 de enero de 1939, según certificaba el Comisariado de dicho Ejército, Miguel Prieto continuaba prestando sus servicios en su Sección de Propaganda y Prensa ${ }^{102}$, pero poco sabemos de la continuidad de su labor respecto al guiñol. Según Rivas Cherif, que se volvió a encontrar con el manchego en esa agobiada Barcelona, cuando ambos estaban desplazados allí, y le llevó a su estudio, "donde daba los últimos toques a su precioso Retablo de Marionetas, en que trabajaba meses y meses que se contaban por años", este último esfuerzo tuvo un trágico final:

A punto de poder ofrecer sus primeros espectáculos, magníficos que hubieran sido por el ingenio de aquel artificio de muñecos, cada uno de los cuales representaba el esfuerzo de una escultura, policromada la cabeza, y vestida a lo profano como las más ricas imágenes religiosas de los pueblos españoles, por la suntuosidad y alegría pictórica de los decorados, por la plástica dinámica con que estaba ensayando el espectáculo, bajo su dirección, verdaderamente escenográfica, una bomba, segadora de vidas, sembradora de ruinas, acabó con el teatrillo en ciernes, retablo magnificado del de Maese Pedro ${ }^{103}$.

Siguiendo los pasos del derrotado Ejército del Ebro, el 9 de febrero de 1939 Prieto hubo de cruzar los Pirineos y pasar a Francia, adonde fue recluido, al igual que otros amigos de infortunio (Renau, Serrano Plaja, Herrera Petere, Dieste, Manuel Ángeles Ortiz, Gaya, Gil Albert, Rodríguez Luna, Altolaguirre, etc.), en el campo de concentración de Saint Cyprien. Salió el 28 de febrero y pudo reunirse con su familia en Perpiñán, pasando luego unos breves días en Toulouse y en París. En esta última capital se creó en marzo de 1939 la primera Junta de Cultura Española, de la que entró a formar parte y, el 6 de mayo, junto a otros de sus miembros (José Bergamín, Renau, Prados, Josep Carner, Herrera Petere, Rodríguez Luna, Fernández Balbuena, Eduardo Ugarte, Halffter y otros), gracias a la mediación para reunirlos del pintor mexicano Fernando Gamboa y la conducción de su compatriota Juan de la Cabada, partió con ellos del puerto francés de Saint Nazaire, en el transatlántico holandés Veendam, con destino al país azteca. Tras pasar por Southampton (Gran Bretaña), Halifax (Canadá) y Nueva York (adonde llegaron el 17 de mayo y pasaron tres días), en autobús se dirigieron a la frontera de Nuevo Laredo, que cruzaron el 24 de mayo ${ }^{104}$, arribando a la capital mexicana dos días después ${ }^{105}$.

100 Orden del MIPS de 6-1-1938, Gaceta de la República, n. ${ }^{\circ}$ 18, Barcelona, 18-1-1938, p. 267.

101 Orden del MIPS de 2-3-1938, Gaceta de la República, n. ${ }^{\circ}$ 78, Barcelona, 19-3-1938, p. 1379.

102 Bonet/Brihuega/Perujo: Op. cit., pp. 40-41.

103 Rivas Cherif: Op. cit., 2-9-1956, p. 3.

104 Aunque no se cuenta con la Ficha del Registro Nacional de Extranjeros de México de Miguel Prieto, se conocen las de otros compañeros de aquel viaje, como la de su esposa e hijo (Angelita Ruiz Ramírez y Miguel Prieto Ruiz) o la del pintor Antonio Rodríguez Luna y su hijo, y en ellas se indica que entraron por Nuevo Laredo (Tamaulipas) el 24 de mayo de 1939, en calidad de exiliados políticos (AGA, RIEM 235-103 y 224-156).

105 Bonet/Brinuega/Perujo: Op. cit., pp. 42-45; Cabañas, M.: Op. cit., 2005, p. 57 y Cabañas, M.: “Quijotes en otro suelo, artistas españoles exiliados en México", en Cabañas Bravo, M.; D. Fernández; N. De Haro e I. 
En el exilio de México se abriría un nuevo capítulo en la trayectoria artística de Miguel Prieto, que fue especialmente estimulante en el campo de la escena y que, como avanzamos, queda analizado en otro lugar. Resumamos, no obstante, que la experimentación que pudo desarrollar allí el manchego en el ámbito de la escenografía y los logros alcanzados, resultarían altamente significativos. Es decir, tras su llegada a México, simultaneó las labores de pintor, ilustrador, diseñador gráfico y escenógrafo. Esta última vía era la enseñanza que tenía más próxima y la que primero intentó poner en práctica, reactualizando su experiencia española en torno al teatro de guiñol, aunque sin éxito, debido a los componentes de agitación político-social que introduciría en su temprano proyecto de crear una "escuela-taller" en esta materia. Luego, la puesta en escena de algunos entremeses clásicos, le serviría de actuaciones introductorias en el mundo mexicano de la escena. Pero en breve fue más allá, atreviéndose con experiencias como los decorados para ballet, en los que se inició en 1946 y que funcionaron como una buena plataforma de difusión internacional de su trabajo. Sin embargo, sus más profundas y conseguidas experiencias se dieron a partir de 1952 y en la escenografía teatral, a la que se dedicó prioritariamente desde entonces. Alcanzó con ella grandes y variados logros, como los conseguidos con sus escenografías para No es cordero..., que es cordera de León Felipe (1953), Seis personajes en busca de autor de Pirandello (1954) o Los justos de Camus (1955), que demostraron el ensanchamiento de su bagaje, su inspiración y sus registros creativos.

En todo este nuevo discurrir del exilio fue fundamental la formación y experiencia que traía de España, donde las inició desde el grado más combativo y cercano al pueblo que podía prestar un simple guiñol; convencido, junto a esos intelectuales y creadores con quienes colaboró tan de cerca, que la escena podía ser un excelente vehículo de cultura y un inmejorable instrumento para educar e instruir al pueblo. Su exilio en tierras mexicanas al finalizar la guerra civil, que tanto retrasaría luego su "re-conocimiento" en su país de origen, inicialmente también le provocaron hondos y sentidos desacomodos y disociaciones, pero asimismo ello le obligaría a adentrarse en nuevas experiencias y a explorar otros amarres, que mantuvieron su plástica en constante experimentación y ensancharon y enriquecieron sus formas y circunstancias creativas.

Fecha de recepción: 10-I-2011

Fecha de aceptación: 13-VI-2011

Murga (coors.): Analogías en el arte, la literatura y el pensamiento del exilio español de 1939, Madrid, CSIC, 2010, pp. 30-32.

Arch. esp. arte, LXXXIV, 336, octUBRE-DICIEMBRE 2011, 355-378, ISSN: 0004-0428 